Article

\title{
Disulfated Ophiuroid Type Steroids from the Far Eastern Starfish Pteraster marsippus and Their Cytotoxic Activity on the Models of 2D and 3D Cultures
}

\author{
Alla A. Kicha *D, Anatoly I. Kalinovsky, Timofey V. Malyarenko, Olesya S. Malyarenko (D, Svetlana P. Ermakova, \\ Roman S. Popov, Valentin A. Stonik and Natalia V. Ivanchina (D)
}

Citation: Kicha, A.A.; Kalinovsky, A.I.; Malyarenko, T.V.; Malyarenko, O.S.; Ermakova, S.P.; Popov, R.S.;

Stonik, V.A.; Ivanchina, N.V. Disulfated Ophiuroid Type Steroids from the Far Eastern Starfish Pteraster marsippus and Their Cytotoxic Activity on the Models of 2D and 3D Cultures. Mar. Drugs 2022, 20, 164. https://doi.org/10.3390/md20030164 Academic Editor: Marie-Lise Bourguet-Kondracki

Received: 31 January 2022 Accepted: 22 February 2022 Published: 24 February 2022

Publisher's Note: MDPI stays neutral with regard to jurisdictional claims in published maps and institutional affiliations.

Copyright: () 2022 by the authors Licensee MDPI, Basel, Switzerland. This article is an open access article distributed under the terms and conditions of the Creative Commons Attribution (CC BY) license (https:/ / creativecommons.org/licenses/by/ $4.0 /)$.
G.B. Elyakov Pacific Institute of Bioorganic Chemistry, Far Eastern Branch of the Russian Academy of Sciences, Pr. 100-let Vladivostoku 159, 690022 Vladivostok, Russia; kaaniw@piboc.dvo.ru (A.I.K.); malyarenko-tv@mail.ru (T.V.M.); malyarenko.os@gmail.com (O.S.M.); svetlana_ermakova@hotmail.com (S.P.E.); prs_90@mail.ru (R.S.P.); stonik@piboc.dvo.ru (V.A.S.); ivanchina@piboc.dvo.ru (N.V.I.)

* Correspondence: kicha@piboc.dvo.ru; Tel.: +7-423-2312-360; Fax: +7-423-2314-050

\begin{abstract}
New steroidal 3 $\beta, 21$-disulfates (2-4), steroidal 3 $\beta, 22$-disulfate (5), and the previously known related steroidal $3 \beta, 21$-disulfate (1) were isolated from the ethanolic extract of the Far Eastern starfish Pteraster marsippus, collected off Urup Island in the Sea of Okhotsk. The structures of these compounds were determined by intensive NMR and HRESIMS techniques as well as by chemical transformations. Steroids 2 and 3 have an oxo-group in the tetracyclic nucleus at position C-7 and differ from each other by the presence of the 5(6)-double bond. The $\Delta^{24}$-22-sulfoxycholestane side chain of the steroid 5 has not been found previously in the starfish or ophiuroid steroids. The cytotoxic activities of $\mathbf{1}, \mathbf{4}, \mathbf{5}$, and the mixture of $\mathbf{2}$ and $\mathbf{3}$ were determined on the models of $2 \mathrm{D}$ and 3D cultures of human epithelial kidney cells (HEK293), melanoma cells (SK-MEL-28), small intestine carcinoma cells (HuTu80), and breast carcinoma cells (ZR-75-1). The mixture of 2 and 3 revealed a significant inhibitory effect on the cell viability of human breast carcinoma ZR-75-1 cells, but other tested compounds were less effective.
\end{abstract}

Keywords: disulfated steroids; NMR spectra; starfish; Pteraster marsippus; cytotoxic activity; 3D culture

\section{Introduction}

Marine sulfated steroids are often found in representatives of two classes of marine echinoderms, namely ophiuroids and particularly starfish (the phylum Echinodermata), and in sponges (the phylum Porifera) [1,2]. These compounds have been reported to exhibit various biological activities, including anticancer, antimicrobial, cardiovascular, and antifouling properties [3]. Steroidal monosulfates, encountered in different species of starfish, are represented by sterol sulfates and polyhydroxysteroids, containing from four to nine hydroxy groups and a sulfate group at different positions of the tetracyclic core and side chains. In that position, the polyhydroxysteroids were found in both free and glycosylated forms with one to three monosaccharide units and also were found in sulfated form. Moreover, the most common steroidal oligoglycosides of starfish are known as classical asterosaponins and contain an oligosaccharide chain, attached to C-6 and including five or six monosaccharide residues and a sulfate group at C-3 [4-10]. On the other hand, characteristic secondary metabolites of ophiuroids are mainly steroidal disulfates that differ from other sulfated compounds of echinoderms in some structural peculiarities, namely in the presence of sulfoxy groups at $3 \alpha$ and 21 positions in $5 \beta-$, or $\Delta^{5}-$, and very rarely $5 \alpha$-cholestane cores. It is of interest, that similar steroidal disulfates, containing sulfoxy groups at $3 \beta$ (or $3 \alpha$ ) and 21 positions in $5 \alpha-$, or $\Delta^{5}$-cholestane nuclei were found in some species of the Pterasteridae family belonging to the Asteroidea class. From six species of starfish belonging to the Pterasteridae family, in particular Euretaster insignis [11], Pteraster sp. and Pteraster tessellatus [12,13], 
Diplopteraster multipes [14], Pteraster pulvillus [15], and Pteraster obscurus [16], nine new disulfated steroidal compounds and six compounds studied as desulfated derivatives, obtained after solvolytic desulfation have been structurally described. At the same time, the polyhydroxylated steroids and asterosaponins, common in starfish, were absent in the studied starfish species belonging to the family Pterasteridae. Based on the structural similarity of steroidal disulfates isolated from this family of starfish and from different ophiuroids, it was assumed that there is a closer phylogenetic relationship between the Asteroidea and Ophiuroidea classes than other classes of Echinodermata [13].

At the present time, structural studies on steroidal disulfates from starfish and ophiuroids are somewhat ahead of the investigation of their biological activities. Nevertheless, the steroidal metabolites of ophiuroids were reported to inhibit the protein tyrosine kinase (PTK) [17], to show antiviral activity against HIV-1 and HIV-2 [18], and to be potent antagonists of farnesoid-X-receptor (FXR), a ligand-regulated transcription factor involved in the supporting of the lipid and glucose homeostasis in mammals [19]. These compounds enhanced oxygen-dependent metabolism, increased adhesive and phagocytic properties, induced the expression of pro-inflammatory cytokines TNF- $\alpha$ and IL-8 in neutrophils, and enhanced the production of antibody-forming cells in the mouse spleen [20]. Biological activities of steroidal disulfates from Pterasteridae starfish were less studied, but hemolytic activity on mouse erythrocytes was reported [15]. Thereby, the investigation of the biological activities of steroidal disulfates of starfish and ophiuroids requires further continuation.

In the present article, we describe the results of our study on the fraction of sulfated steroids from the ethanolic extract of the Far Eastern starfish Pteraster marsippus Fisher, 1910 (order Velatida, family Pterasteridae) collected by trawling at a depth of $84-88 \mathrm{~m}$ in the Sea of Okhotsk near Urup Island. We have isolated and structurally elucidated four new disulfated steroids $\mathbf{2}-\mathbf{5}$ along with one previously known related compound $\mathbf{1}$. Additionally, the cytotoxic activities of $\mathbf{1}, \mathbf{4}, \mathbf{5}$, and the mixture of $\mathbf{2}$ and $\mathbf{3}$ on the models of $2 \mathrm{D}$ and 3D cancer cell cultures have been determined.

\section{Results}

\subsection{The Isolation and Structure Elucidation of Compounds 1-5 from P. marsippus}

The ethanol extract of the starfish P. marsippus was separated by column chromatography on Polychrome 1, Si gel, and Florisil followed by reversed-phase HPLC on semipreparative Discovery C18 and analytical YMC-Pack Pro C18 columns to give four new disulfated steroids $\mathbf{2} \mathbf{- 5}$ along with one previously known related compound $\mathbf{1}$ (Figure $\mathbf{1}$ ).

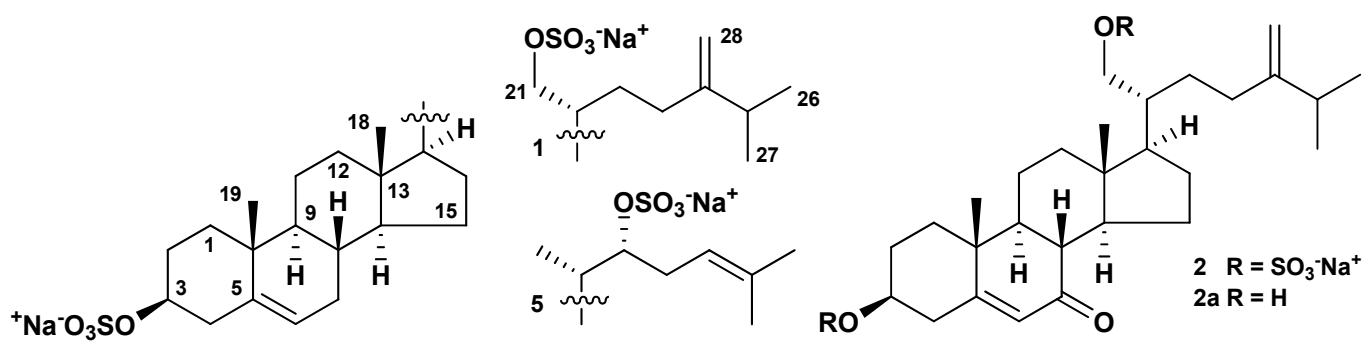

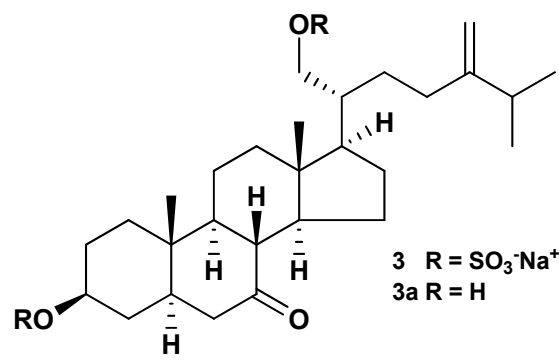

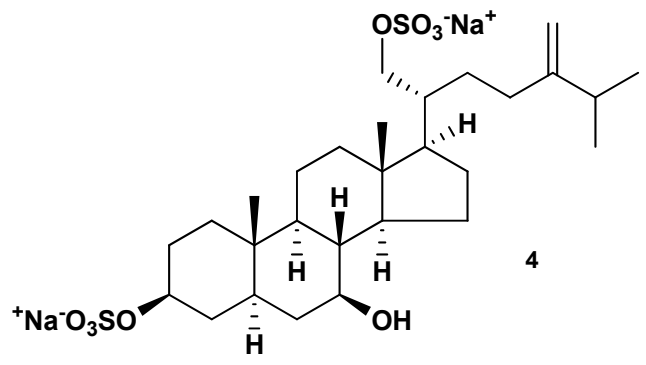

Figure 1. Structures of compounds 1-5 isolated from P. marsippus. 
The molecular formula of steroid 1 was established to be $\mathrm{C}_{28} \mathrm{H}_{44} \mathrm{Na}_{2} \mathrm{O}_{8} \mathrm{~S}_{2}$ from the $[\mathrm{M}-\mathrm{Na}]^{-}$and $[\mathrm{M}-2 \mathrm{Na}]^{2-}$ ion peaks at $m / z 595.2388$ and 286.1253 in the (-)HRESIMS, respectively, and from the $[\mathrm{M}+\mathrm{Na}]^{+}$sodium adduct ion peak at $m / z 641.2154$ in the (+)HRESIMS (Figure S1). The presence of sulfate groups in $\mathbf{1}$ is confirmed by HRESIMS as well as by the presence in the (-)HRESIMS/MS spectrum of $[\mathrm{M}-2 \mathrm{Na}]^{2-}$ ion of fragment ions at $m / z 96.9610\left[\mathrm{HSO}_{4}\right]^{-}, 136.9917\left[\mathrm{C}_{3} \mathrm{H}_{5} \mathrm{O}_{4} \mathrm{~S}\right]^{-}, 391.1958\left[\mathrm{M}-\mathrm{Na}-\mathrm{NaHSO}_{4}-\mathrm{C}_{6} \mathrm{H}_{12}\right]^{-}$, $459.2584\left[\mathrm{M}-\mathrm{Na}-\mathrm{NaHSO}_{4}-\mathrm{CH}_{4}\right]^{-}$, and $475.2898\left[\mathrm{M}-\mathrm{Na}-\mathrm{NaHSO}_{4}\right]^{-}$. The ${ }^{1} \mathrm{H}^{-}$ and ${ }^{13} \mathrm{C}$-NMR spectroscopic data attributable to the tetracyclic nucleus of 1 revealed the proton and carbon chemical shifts of two angular methyl groups $\mathrm{CH}_{3}-18\left(\delta_{\mathrm{H}} 0.75 \mathrm{~s}, \delta_{\mathrm{C}} 12.5\right)$ and $\mathrm{CH}_{3}-19\left(\delta_{\mathrm{H}} 1.03 \mathrm{~s}, \delta_{\mathrm{C}} 19.7\right)$, an oxygenated methine $\mathrm{CH}-3\left(\delta_{\mathrm{H}} 4.13 \mathrm{~m}, \delta_{\mathrm{C}} 79.9\right)$, and the 5(6) double bond $\left(\delta_{\mathrm{H}} 5.38 \mathrm{~m} ; \delta_{\mathrm{C}} 141.7,123.2\right)$. The proton and carbon resonances of $\mathrm{CH}_{3}-18, \mathrm{CH}_{3}-19, \mathrm{CH}-3, \mathrm{C}-5, \mathrm{CH}-6$ and the broad multiplet of $\mathrm{H}-3(\Delta W=39.3 \mathrm{~Hz})$ indicated a $\Delta^{5}-3 \beta$-sulfoxy steroidal nucleus in $\mathbf{1}$ [11].

The proton and carbon signals belonging to the side chain of $\mathbf{1}$ showed the presence of two secondary methyls $\mathrm{CH}_{3}-26\left[\delta_{\mathrm{H}} 1.02 \mathrm{~d}(J=6.8) ; \delta_{\mathrm{C}} 22.4\right]$ and $\mathrm{CH}_{3}-27\left[\delta_{\mathrm{H}} 1.03 \mathrm{~d}\right.$ $\left.(J=6.8) ; \delta_{\mathrm{C}} 22.5\right]$, an distinctive oxygenated methylene $\mathrm{CH}_{2}-21\left[\delta_{\mathrm{H}} 4.21 \mathrm{dd}(J=9.8,3.7)\right.$, $\left.3.94 \mathrm{dd}(J=9.8,6.4) ; \delta_{\mathrm{C}} 69.3\right]$, and the $24(28)$ double bond $\left[\delta_{\mathrm{H}} 4.71 \mathrm{br} \mathrm{s}, 4.68 \mathrm{br} \mathrm{d}(J=1.3)\right.$; $\left.\delta_{C} 157.9,106.9\right]$. These data testified about the $\Delta^{24(28)}-21$-sulfoxy-24-methylcholestane side chain in $\mathbf{1}$ [11,16]. An analysis of the COSY, HSQC, HMBC, and ROESY spectra supported the proposed structure of tetracyclic and side-chain moieties and allowed us to define all the proton and carbon signals in 1 (Tables 1 and 2, Figures S2-S7). The COSY and HSQC experiments showed a spin coupling system of the protons at C-1 to C-4, C- 6 to C-12 through C-11, C-14 to C-17, C-17 to C-21 through C-20, C-20 to C-23, and at C-25 to C-26 and C-27 (Figures S4 and S5). The overall steroid structure of 1 was confirmed by the key HMBC correlations $\mathrm{H}_{3}-18 / \mathrm{C}-12$, C-13, C-14, C-17; H3-19/C-1, C-5, C-9, C-10; H $2-21$ /C-17, C-20; $\mathrm{H}-25 / \mathrm{C}-26, \mathrm{C}-27 ; \mathrm{H}_{3}-26 / \mathrm{C}-24 ;$ and $\mathrm{H}_{2}-28 / \mathrm{C}-25, \mathrm{C}-26$ (Figure S6). The presence of the key ROESY cross-peaks H $\alpha-4 / \mathrm{H}-6$; H-9/H $\alpha-1, \mathrm{H} \alpha-7$; $\mathrm{H} \alpha-16 / \mathrm{H}-17$; $\mathrm{H} \beta-16 / \mathrm{H}-20 ; \mathrm{H}_{3}-18 / \mathrm{H}-8$, $\mathrm{H} \beta-12, \mathrm{H} \beta-15, \mathrm{H} \beta-16 ; \mathrm{H}_{3}-19 / \mathrm{H} \beta-1, \mathrm{H} \beta-2, \mathrm{H} \beta-4 ; \mathrm{H}-28 / \mathrm{H}_{2}-22, \mathrm{H}_{2}-23$; and $\mathrm{H}^{\prime}-28 / \mathrm{H}-25$, $\mathrm{H}_{3}-26, \mathrm{H}_{3}-27$ exhibited the $\Delta^{5,24(28)}-24$-methylcholestane skeleton in 1 (Figure S7). The $20 R$ configuration was determined based on the ROESY correlations of $\mathrm{H} \beta-12 / \mathrm{H}-20, \mathrm{H}_{3}-$ $18 / \mathrm{H}-20, \mathrm{H}_{2}-21$ [21] and the coupling constants and chemical shifts of the methylene group $\mathrm{CH}_{2}-21$, which were close to similar values in the ${ }^{1} \mathrm{H}$ - and ${ }^{13} \mathrm{C}-\mathrm{NMR}$ spectra of related previously studied (20R)-21-sulfoxysteroids from starfish and ophiuroids [11,13-16,22]. Thus, the structure (20R)-24-methylcholesta-5,24(28)-diene-3 $\beta, 21$-diyl disulfate disodium salt was assigned for $\mathbf{1}$. Compound $\mathbf{1}$ was previously found in the mixture of disulfated $3 \beta, 21$-dihydroxysteroids from the starfish Euretaster insignis [11]. Its structure was proposed on the basis of the structure definition of the desulfated derivative, (20R)-24-methylcholesta5,24(28)-diene-3,21-diol, obtained by solvolysis of the steroid mixture followed by HPLC separation. The ${ }^{1} \mathrm{H}$ - and ${ }^{13} \mathrm{C}-\mathrm{NMR}$ spectroscopic data of $\mathbf{1}$ itself are presented here for the first time.

An attempt to separate compounds 2 and 3 using repeated reversed-phase HPLC were failed. However, structures of $\mathbf{2}$ and $\mathbf{3}$ were established in the mixture by the thorough analysis of the 1D and 2D NMR spectra, including ${ }^{1} \mathrm{H}$ - and ${ }^{13} \mathrm{C}-\mathrm{NMR}, 1 \mathrm{D}$ TOCSY, COSY, HSQC, HMBC, and ROESY experiments (Figures S8-S13). The molecular formula of steroid 2 was determined to be $\mathrm{C}_{28} \mathrm{H}_{42} \mathrm{Na}_{2} \mathrm{O}_{9} \mathrm{~S}_{2}$ from the $[\mathrm{M}-\mathrm{Na}]^{-}$and $[\mathrm{M}-2 \mathrm{Na}]^{2-}$ ion peaks at $m / z$ 609.2177 and 293.1148 in the (-)HRESIMS, respectively, and from the $[\mathrm{M}+\mathrm{Na}]^{+}$sodium adduct ion peak at $m / z 655.1943$ in the (+)HRESIMS (Figure S14). The presence of sulfate groups in $\mathbf{2}$ is confirmed by HRESIMS as well as by the presence in the (-)HRESIMS/MS spectrum of $[\mathrm{M}-2 \mathrm{Na}]^{2-}$ of fragment ions at $m / z 96.9612\left[\mathrm{HSO}_{4}\right]^{-}, 136.9917\left[\mathrm{C}_{3} \mathrm{H}_{5} \mathrm{O}_{4} \mathrm{~S}\right]^{-}$, $405.1745\left[\mathrm{M}-\mathrm{Na}-\mathrm{NaHSO}_{4}-\mathrm{C}_{6} \mathrm{H}_{12}\right]^{-}$and $489.2682\left[\mathrm{M}-\mathrm{Na}-\mathrm{NaHSO}_{4}\right]^{-}$. The molecular formula of steroid 3 was established to be $\mathrm{C}_{28} \mathrm{H}_{44} \mathrm{Na}_{2} \mathrm{O}_{9} \mathrm{~S}_{2}$ from the $[\mathrm{M}-\mathrm{Na}]^{-}$and $[\mathrm{M}-2 \mathrm{Na}]^{2-}$ ion peaks at $m / z 611.2299$ and 294.1222 in the $(-)$ HRESIMS, respectively, and from the $[\mathrm{M}+\mathrm{Na}]^{+}$sodium adduct ion peak at $m / z 657.2077$ in the (+)HRESIMS (Figure S14). The presence of sulfate groups in 3 is confirmed by HRESIMS as well as 
by the presence in the (-)HRESIMS/MS spectrum of $[\mathrm{M}-2 \mathrm{Na}]^{2-}$ of fragment ions at $m / z 96.9612\left[\mathrm{HSO}_{4}\right]^{-}, 136.9917\left[\mathrm{C}_{3} \mathrm{H}_{5} \mathrm{O}_{4} \mathrm{~S}\right]^{-}, 407.1891\left[\mathrm{M}-\mathrm{Na}-\mathrm{NaHSO}_{4}-\mathrm{C}_{6} \mathrm{H}_{12}\right]^{-}$, and $491.2825\left[\mathrm{M}-\mathrm{Na}-\mathrm{NaHSO}_{4}\right]^{-}$. The detailed comparison of the ${ }^{1} \mathrm{H}-$ and ${ }^{13} \mathrm{C}-\mathrm{NMR}$, mass spectra of $\mathbf{1}$, and the mixture of $\mathbf{2}$ and $\mathbf{3}$ clearly indicated that these compounds have the same $\Delta^{24(28)}$-21-sulfoxy-24-methylcholestane side chain, and steroids $\mathbf{2}$ and $\mathbf{3}$ differ from 1 by the existence of an additional oxo-group in tetracyclic pattern (Tables 1 and 2). Moreover, it followed from the chemical shifts and intensities of the proton signals in the ${ }^{1} \mathrm{H}$-NMR spectrum that 2 unlike 3 has a supplementary double bond in the steroidal nucleus, which agreed with the molecular mass difference of $2 \mathrm{amu}$ between 2 and 3 in the mass-spectra.

The proton and carbon resonances of two angular methyl groups $\mathrm{CH}_{3}-18\left(\delta_{\mathrm{H}} 0.75 \mathrm{~s}\right.$, $\left.\delta_{\mathrm{C}} 12.7\right)$ and $\mathrm{CH}_{3}-19\left(\delta_{\mathrm{H}} 1.24 \mathrm{~s}, \delta_{\mathrm{C}} 17.6\right)$, an oxygenated methine $\mathrm{CH}-3\left(\delta_{\mathrm{H}} 4.26 \mathrm{~m}, \delta_{\mathrm{C}} 78.0\right)$, a $5(6)$ double bond $\left[\delta_{\mathrm{H}} 5.68 \mathrm{brd}(J=1.6) ; \delta_{\mathrm{C}} 168.3,126.8\right]$, and a 7 -oxo group $\left(\delta_{\mathrm{C}} 204.4\right)$ attributable to the tetracyclic moiety of 2 were observed in the ${ }^{1} \mathrm{H}$ - and ${ }^{13} \mathrm{C}-\mathrm{NMR}$ spectra. These values of chemical shifts allowed us to suppose a $\Delta^{5}-7$-oxo- $3 \beta$-sulfoxy steroidal nucleus in 2. The COSY and HSQC experiments led to the identification of the proton sequences at $\mathrm{C}-1$ to $\mathrm{C}-4, \mathrm{C}-8$ to $\mathrm{C}-12$ through $\mathrm{C}-11, \mathrm{C}-8$ to $\mathrm{C}-17$ through $\mathrm{C}-14, \mathrm{C}-17$ to $\mathrm{C}-21$ through C-20, C-20 to C-23, and at C-25 to C-26 and C-27 (Figure 2). Since it is difficult to identify some proton signals in the ${ }^{1} \mathrm{H}-\mathrm{NMR}$ spectrum of a mixture of two compounds only using 2D NMR experiments, the irradiation of protons $\mathrm{H} \alpha-2, \mathrm{H} \beta-4, \mathrm{H}-6$, and $\mathrm{H}-8$ of 2 in the 1D TOCSY experiments was additionally performed, which gave enhancing signals of the neighboring protons $\mathrm{H}_{2}-1, \mathrm{H} \beta-2, \mathrm{H}-3$, and $\mathrm{H}_{2}-4 ; \mathrm{H}_{2}-1, \mathrm{H}_{2}-2, \mathrm{H}-3$, and $\mathrm{H} \alpha-4 ; \mathrm{H}-3$ and $\mathrm{H}_{2}-4$; and $\mathrm{H}-9, \mathrm{H}-11, \mathrm{H}-14$, and $\mathrm{H} \beta-15$, respectively. The key HMBC correlations $\mathrm{H}-4 / \mathrm{C}-5$, C-6; $\mathrm{H}-8 / \mathrm{C}-7, \mathrm{C}-9 ; \mathrm{H}-17 / \mathrm{C}-20, \mathrm{C}-21, \mathrm{C}-22 ; \mathrm{H}_{3}-18 / \mathrm{C}-12$, C-13, C-14, C-17; $\mathrm{H}_{3}-19 / \mathrm{C}-1$, C-5, C-9, C-10; and $\mathrm{H}_{3}-26 / \mathrm{C}-24, \mathrm{C}-25, \mathrm{C}-28$; and the key ROESY correlations $\mathrm{H} \alpha-1 / \mathrm{H}-9$; $\mathrm{H} \alpha-4 / \mathrm{H}-6$; $\mathrm{H} \beta-12 / \mathrm{H}_{2}-21 ; \mathrm{H}-14 / \mathrm{H} \alpha-16 ; \mathrm{H}_{3}-18 / \mathrm{H}-8, \mathrm{H} \beta-11, \mathrm{H}-20, \mathrm{H}_{2}-21 ; \mathrm{H}_{3}-19 / \mathrm{H} \beta-1, \mathrm{H} \beta-2, \mathrm{H} \beta-4$, $\mathrm{H}-8, \mathrm{H} \beta-11 ; \mathrm{H}-28 / \mathrm{H}_{2}-22, \mathrm{H}_{2}-23$; and $\mathrm{H}^{\prime}-28 / \mathrm{H}-25, \mathrm{H}_{3}-26, \mathrm{H}_{3}-27$ exhibited a $3 \beta$,21-disulfoxy7 -oxo pattern in the $\Delta^{5,24(28)}$-24-methylcholestane skeleton in 2 (Figures 2 and 3). Based on the above-mentioned data, the structure of 2 was defined as (20R)-7-oxo-24-methylcholesta5,24(28)-diene-3 $\beta, 21$-diyl disulfate disodium salt.
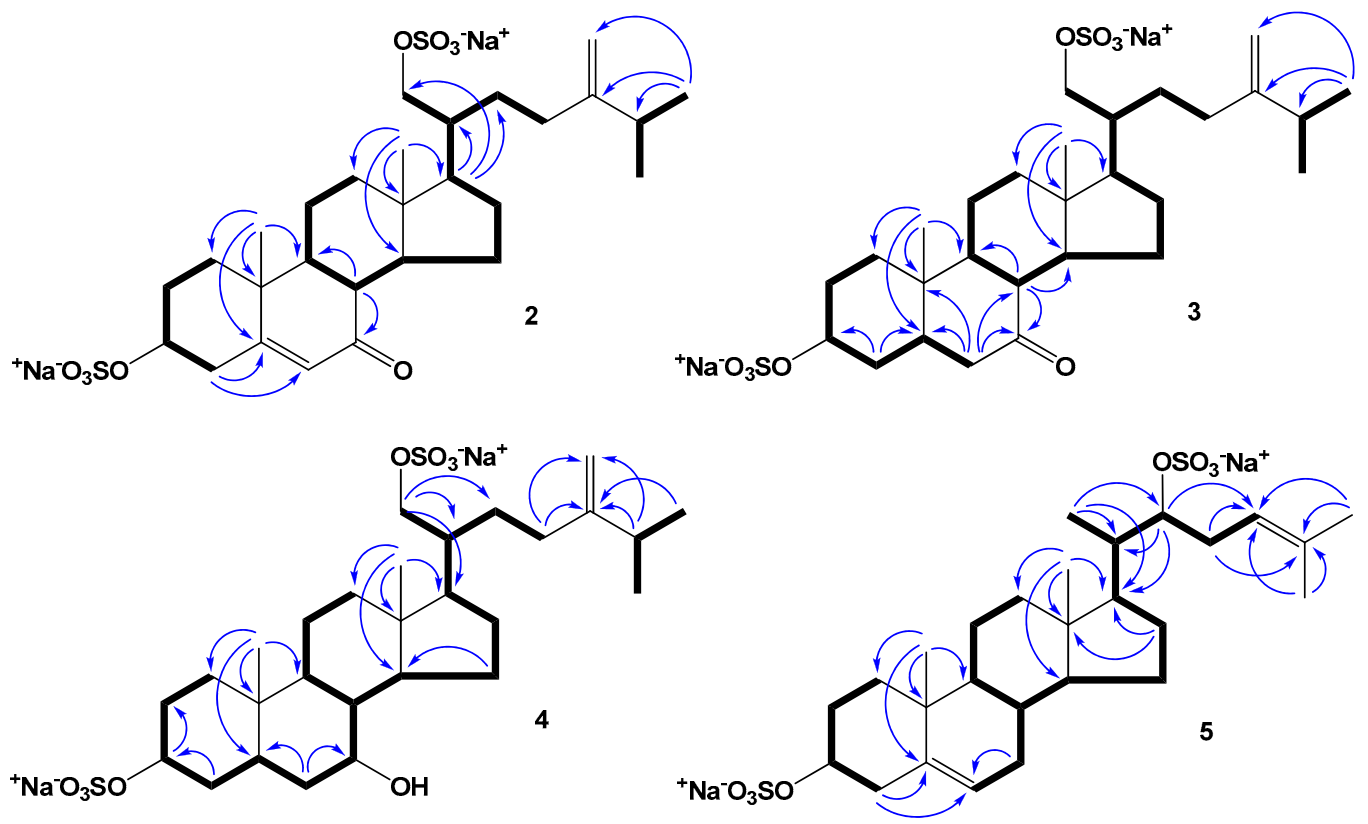

Figure 2. COSY and key HMBC correlations of compounds 2-5. 
Table 1. ${ }^{1} \mathrm{H}-\mathrm{NMR}(700.13 \mathrm{MHz})$ chemical shifts of compounds $\mathbf{1}-\mathbf{5}$ in $\mathrm{CD}_{3} \mathrm{OD}$, with $\delta$ in ppm and $J$ values in $\mathrm{Hz}^{a}$.

\begin{tabular}{|c|c|c|c|c|c|}
\hline Position & 1 & 2 & 3 & 4 & 5 \\
\hline $1 \beta$ & $1.89 \mathrm{dt}(13.8,3.7)$ & $2.02 \mathrm{dt}(13.9,3.7)$ & $1.81 \mathrm{dt}(13.9,3.5)$ & $1.76 \mathrm{dt}(13.8,3.7)$ & $1.89 \mathrm{dt}(13.5,3.5)$ \\
\hline$\alpha$ & $1.11 \mathrm{~m}$ & $1.26 \operatorname{td}(13.9,3.5)$ & 1.07 td $(13.9,3.7)$ & $0.98 \operatorname{td}(13.8,3.8)$ & $1.11 \mathrm{~m}$ \\
\hline $2 \alpha$ & $2.05 \mathrm{~m}$ & $2.15 \mathrm{~m}$ & $2.06 \mathrm{~m}$ & $2.02 \mathrm{~m}$ & $2.05 \mathrm{~m}$ \\
\hline$\beta$ & $1.63 \mathrm{~m}$ & $1.76 \mathrm{~m}$ & $1.60 \mathrm{~m}$ & $1.53 \mathrm{~m}$ & $1.62 \mathrm{~m}$ \\
\hline 3 & $4.13 \mathrm{~m}(\Delta W=39.3 \mathrm{~Hz})$ & $4.26 \mathrm{~m}$ & $4.25 \mathrm{~m}$ & $4.24 \mathrm{~m}$ & $4.13 \mathrm{~m}$ \\
\hline $4 \alpha$ & 2.53 ddd $(13.2,4.8,2.2)$ & $2.79 \mathrm{ddd}(14.0,5.0,2.3)$ & $1.86 \mathrm{~m}$ & $1.81 \mathrm{~m}$ & 2.53 ddd $(13.4,4.8,2.2)$ \\
\hline$\beta$ & $2.34 \mathrm{td}(13.2,2.0)$ & 2.54 ddd $(14.0,11.8,1.9)$ & $1.57 \mathrm{~m}$ & $1.43 \mathrm{~m}$ & $2.33 \mathrm{~m}$ \\
\hline 5 & - & - & $1.52 \mathrm{~m}$ & $1.22 \mathrm{~m}$ & - \\
\hline $\begin{array}{c}6 \beta \\
\alpha\end{array}$ & $5.38 \mathrm{~m}$ & $5.68 \mathrm{br} \mathrm{d}(1.6)$ & $\begin{array}{c}2.46 \mathrm{t}(12.3) \\
1.94 \mathrm{dd}(12.3,3.2)\end{array}$ & $\begin{array}{c}1.33 \mathrm{t} \mathrm{(12.8)} \\
1.55 \mathrm{~m}\end{array}$ & $5.38 \mathrm{~m}$ \\
\hline $\begin{array}{c}7 \beta \\
\alpha\end{array}$ & $\begin{array}{l}1.97 \mathrm{~m} \\
1.56 \mathrm{~m}\end{array}$ & - & - & $3.25 \operatorname{td}(10.6,5.2)$ & $\begin{array}{l}1.96 \mathrm{~m} \\
1.54 \mathrm{~m}\end{array}$ \\
\hline 8 & $1.48 \mathrm{~m}$ & $2.31 \mathrm{dd}(12.6,10.7)$ & $2.47 \mathrm{~m}$ & $1.40 \mathrm{~m}$ & $1.47 \mathrm{~m}$ \\
\hline 9 & 0.97 td $(11.7,4.6)$ & $1.53 \mathrm{~m}$ & $1.09 \mathrm{~m}$ & $0.71 \mathrm{~m}$ & $0.96 \mathrm{~m}$ \\
\hline 10 & - & - & - & - & - \\
\hline $\begin{array}{c}11 \alpha \\
\beta\end{array}$ & $\begin{array}{l}1.57 \mathrm{~m} \\
1.04 \mathrm{~m}\end{array}$ & $1.63 \mathrm{~m}$ & $\begin{array}{l}1.62 \mathrm{~m} \\
1.55 \mathrm{~m}\end{array}$ & $\begin{array}{l}1.58 \mathrm{~m} \\
1.35 \mathrm{~m}\end{array}$ & $\begin{array}{l}1.54 \mathrm{~m} \\
1.05 \mathrm{~m}\end{array}$ \\
\hline $\begin{array}{c}12 \beta \\
\alpha\end{array}$ & $\begin{array}{c}2.04 \mathrm{~m} \\
1.25 \mathrm{td}(13.0,4.2)\end{array}$ & $\begin{array}{l}2.07 \mathrm{~m} \\
1.22 \mathrm{~m}\end{array}$ & $\begin{array}{l}2.02 \mathrm{~m} \\
1.16 \mathrm{~m}\end{array}$ & $\begin{array}{l}1.99 \mathrm{~m} \\
1.19 \mathrm{~m}\end{array}$ & $\begin{array}{l}2.01 \mathrm{dt}(12.8,3.5) \\
1.23 \mathrm{td}(12.8,4.2)\end{array}$ \\
\hline 13 & - & - & - & - & - \\
\hline 14 & $1.06 \mathrm{~m}$ & $1.35 \mathrm{~m}$ & $1.47 \mathrm{~m}$ & $1.19 \mathrm{~m}$ & $1.09 \mathrm{~m}$ \\
\hline $15 \alpha$ & $1.64 \mathrm{~m}$ & $2.40 \mathrm{~m}$ & $2.20 \mathrm{~m}$ & $1.90 \mathrm{~m}$ & $1.61 \mathrm{~m}$ \\
\hline$\beta$ & $1.13 \mathrm{~m}$ & $1.28 \mathrm{~m}$ & $1.02 \mathrm{~m}$ & $1.48 \mathrm{~m}$ & $1.09 \mathrm{~m}$ \\
\hline $16 \alpha$ & $1.87 \mathrm{~m}$ & $1.90 \mathrm{~m}$ & $1.88 \mathrm{~m}$ & $1.83 \mathrm{~m}$ & $2.22 \mathrm{~m}$ \\
\hline$\beta$ & $1.37 \mathrm{~m}$ & $1.39 \mathrm{~m}$ & $1.35 \mathrm{~m}$ & $1.34 \mathrm{~m}$ & $1.16 \mathrm{~m}$ \\
\hline 17 & $1.48 \mathrm{~m}$ & $1.48 \mathrm{~m}$ & $1.48 \mathrm{~m}$ & $1.43 \mathrm{~m}$ & $1.63 \mathrm{~m}$ \\
\hline 18 & $0.75 \mathrm{~s}$ & $0.75 \mathrm{~s}$ & $0.72 \mathrm{~s}$ & $0.73 \mathrm{~s}$ & $0.70 \mathrm{~s}$ \\
\hline 19 & $1.03 \mathrm{~s}$ & $1.24 \mathrm{~s}$ & $1.12 \mathrm{~s}$ & $0.86 \mathrm{~s}$ & $1.02 \mathrm{~s}$ \\
\hline 20 & $1.72 \mathrm{~m}$ & $1.69 \mathrm{~m}$ & $1.69 \mathrm{~m}$ & $1.68 \mathrm{~m}$ & $1.58 \mathrm{~m}$ \\
\hline 21 & $\begin{array}{l}4.21 \mathrm{dd}(9.8,3.7) \\
3.94 \mathrm{dd}(9.8,6.4)\end{array}$ & $\begin{array}{l}4.18 \mathrm{dd}(9.6,4.0) \\
3.99 \mathrm{dd}(9.6,5.7)\end{array}$ & $\begin{array}{l}4.17 \mathrm{dd}(9.6,4.1) \\
3.96 \mathrm{dd}(9.6,5.7)\end{array}$ & $\begin{array}{l}4.18 \mathrm{dd}(9.7,3.8) \\
3.94 \mathrm{dd}(9.7,6.2)\end{array}$ & $0.96 \mathrm{~d}(6.7)$ \\
\hline 22 & $\begin{array}{l}1.64 \mathrm{~m} \\
1.48 \mathrm{~m}\end{array}$ & $\begin{array}{l}1.64 \mathrm{~m} \\
1.49 \mathrm{~m}\end{array}$ & $\begin{array}{l}1.64 \mathrm{~m} \\
1.49 \mathrm{~m}\end{array}$ & $\begin{array}{l}1.64 \mathrm{~m} \\
1.48 \mathrm{~m}\end{array}$ & $4.36 \mathrm{dd}(10.6,4.5)$ \\
\hline 23 & $\begin{array}{c}2.17 \mathrm{ddd}(15.0,11.1,4.6) \\
2.04 \mathrm{~m}\end{array}$ & $\begin{array}{l}2.19 \mathrm{~m} \\
2.02 \mathrm{~m}\end{array}$ & $\begin{array}{l}2.19 \mathrm{~m} \\
2.02 \mathrm{~m}\end{array}$ & $\begin{array}{l}2.17 \mathrm{~m} \\
2.03 \mathrm{~m}\end{array}$ & $\begin{array}{l}2.66 \mathrm{~m} \\
2.34 \mathrm{~m}\end{array}$ \\
\hline 24 & - & - & - & - & $5.05 \mathrm{t}(7.7)$ \\
\hline 25 & 2.25 quin (6.7) & $2.25 \mathrm{~m}$ & $2.25 \mathrm{~m}$ & 2.25 quin & - \\
\hline 26 & $1.02 \mathrm{~d}(6.8)$ & $1.02 \mathrm{~d}(6.8)$ & $1.02 \mathrm{~d}(6.8)$ & $1.02 \mathrm{~d}(6.8)$ & $1.69 \mathrm{~s}$ \\
\hline 27 & $1.03 \mathrm{~d}(6.8)$ & $1.03 \mathrm{~d}(6.8)$ & $1.03 \mathrm{~d}(6.8)$ & $1.03 \mathrm{~d}(6.8)$ & $1.65 \mathrm{~s}$ \\
\hline 28 & $\begin{array}{c}4.71 \text { br s } \\
4.68 \text { br d (1.3) }\end{array}$ & $\begin{array}{l}4.71 \text { br d (1.2) } \\
4.69 \text { br d (1.2) }\end{array}$ & $\begin{array}{l}4.71 \text { br d (1.2) } \\
4.69 \text { br d (1.2) }\end{array}$ & $\begin{array}{c}4.71 \text { br s } \\
4.68 \text { br d (1.5) }\end{array}$ & \\
\hline
\end{tabular}


Table 2. ${ }^{13} \mathrm{C}-\mathrm{NMR}(176.04 \mathrm{MHz})$ chemical shifts of compounds $\mathbf{1}-\mathbf{5}$ in $\mathrm{CD}_{3} \mathrm{OD}$.

\begin{tabular}{|c|c|c|c|c|c|}
\hline Position & 1 & 2 & 3 & 4 & 5 \\
\hline 1 & 38.5 & 37.4 & 37.1 & 38.1 & 38.4 \\
\hline 2 & 30.0 & 29.6 & 29.4 & 29.7 & 30.0 \\
\hline 3 & 79.9 & 78.0 & 78.8 & 79.4 & 79.9 \\
\hline 4 & 40.4 & 40.1 & 36.2 & 35.9 & 40.4 \\
\hline 5 & 141.7 & 168.3 & 48.2 & 43.6 & 141.6 \\
\hline 6 & 123.2 & 126.8 & 46.9 & 39.9 & 123.3 \\
\hline 7 & 33.0 & 204.4 & 214.3 & 75.7 & 33.0 \\
\hline 8 & 33.3 & 46.6 & 51.1 & 44.1 & 33.3 \\
\hline 9 & 51.7 & 51.4 & 56.7 & 54.0 & 51.6 \\
\hline 10 & 37.7 & 39.7 & 37.0 & 36.0 & 37.7 \\
\hline 11 & 22.1 & 22.2 & 22.9 & 22.6 & 22.1 \\
\hline 12 & 40.2 & 39.1 & 39.2 & 40.5 & 41.0 \\
\hline 13 & 43.4 & 44.2 & 43.6 & 44.5 & 43.3 \\
\hline 14 & 58.0 & 51.3 & 50.4 & 57.3 & 58.0 \\
\hline 15 & 25.2 & 27.3 & 25.9 & 27.9 & 25.4 \\
\hline 16 & 28.7 & 28.9 & 28.8 & 29.0 & 29.2 \\
\hline 17 & 51.8 & 50.7 & 50.7 & 51.2 & 53.2 \\
\hline 18 & 12.5 & 12.7 & 12.6 & 12.9 & 12.1 \\
\hline 19 & 19.7 & 17.6 & 12.0 & 12.7 & 19.7 \\
\hline 20 & 41.1 & 41.0 & 41.0 & 41.0 & 39.4 \\
\hline 21 & 69.3 & 69.2 & 69.2 & 69.4 & 12.8 \\
\hline 22 & 29.7 & 29.8 & 29.8 & 29.7 & 82.6 \\
\hline 23 & 31.6 & 31.8 & 31.8 & 31.8 & 31.7 \\
\hline 24 & 157.9 & 157.8 & 157.8 & 157.9 & 121.2 \\
\hline 25 & 34.9 & 34.8 & 34.8 & 34.9 & 134.8 \\
\hline 26 & 22.4 & 22.3 & 22.4 & 22.3 & 26.0 \\
\hline 27 & 22.5 & 22.5 & 22.5 & 22.5 & 18.1 \\
\hline 28 & 106.9 & 107.0 & 107.8 & 106.9 & \\
\hline
\end{tabular}

The ${ }^{1} \mathrm{H}$ - and ${ }^{13} \mathrm{C}-\mathrm{NMR}$ spectroscopic data belonging to the steroidal nucleus of 3 displayed the proton and carbon resonances of two angular methyl groups $\mathrm{CH}_{3}-18\left(\delta_{\mathrm{H}} 0.72 \mathrm{~s}\right.$, $\left.\delta_{\mathrm{C}} 12.6\right)$ and $\mathrm{CH}_{3}-19\left(\delta_{\mathrm{H}} 1.12 \mathrm{~s}, \delta_{\mathrm{C}} 12.0\right)$, an oxygenated methine $\mathrm{CH}-3\left(\delta_{\mathrm{H}} 4.25 \mathrm{~m}, \delta_{\mathrm{C}} 78.8\right)$, and a 7-oxo group $\left(\delta_{\mathrm{C}} 214.3\right)$. These chemical resonances and the absence of a 5(6) double bond corresponded to a 7-oxo-3 $\beta$-sulfoxy tetracyclic pattern in 3 (Tables 1 and 2). The COSY and HSQC experiments revealed a spin coupling system of the protons at $\mathrm{C}-1$ to C-6, C-8 to C-12 through C-11, C-8 to C-17 through C-14, C-17 to C-21 through C-20, C-20 to $C-23$, and at C-25 to C-26 and C-27 (Figure 2). In addition, the irradiation of protons $\mathrm{H} \beta-1$ and $\mathrm{H} \alpha-6$ of 3 in the 1D TOCSY experiments gave the chemical shifts of neighboring protons: $\mathrm{H} \alpha-1, \mathrm{H} \alpha-2, \mathrm{H}-3, \mathrm{H} \alpha-4$, and $\mathrm{H}_{2}-6 ; \mathrm{H}_{2}-1, \mathrm{H} \alpha-2, \mathrm{H}-3, \mathrm{H} \alpha-4$, and $\mathrm{H} \beta-6$, respectively. In the HMBC spectrum the correlations H-4/C-3, C-5; H-6/C-5, C-7, C-8, C-10; H-8/C-9, C-14; $\mathrm{H}_{3}-18 / \mathrm{C}-12$, C-13, C-14, C-17; $\mathrm{H}_{3}-19 / \mathrm{C}-1, \mathrm{C}-5, \mathrm{C}-9$, C-10; and $\mathrm{H}_{3}-26 / \mathrm{C}-24, \mathrm{C}-25$, $\mathrm{C}-28$, and, in the ROESY spectrum, the cross-peaks $\mathrm{H} \beta-12 / \mathrm{H}_{2}-21 ; \mathrm{H} \beta-17 / \mathrm{H}-20 ; \mathrm{H}_{3}-18 / \mathrm{H}-8$, $\mathrm{H} \beta-11, \mathrm{H}-20, \mathrm{H}_{2}-21 ; \mathrm{H}_{3}-19 / \mathrm{H} \beta-1, \mathrm{H} \beta-2, \mathrm{H} \beta-4, \mathrm{H}-8 ; \mathrm{H}-28 / \mathrm{H}_{2}-22, \mathrm{H}_{2}-23$; and $\mathrm{H}^{\prime}-28 / \mathrm{H}-25$, $\mathrm{H}_{3}-26, \mathrm{H}_{3}-27$ indicated a $3 \beta, 21$-disulfoxy-7-oxo substitution in the $\Delta^{24(28)}-24$-methyl-5 $\alpha$ - 
cholestane skeleton in 3 (Figures 2 and 3). Thus, the structure of 3 was determined as (20R)-7-oxo-24-methyl-5 $\alpha$-cholest-24(28)-ene-3 $\beta$,21-diyl disulfate disodium salt. Evaluation of the intensities of the $\mathrm{CH}_{3}-18$ and $\mathrm{CH}_{3}-19$ signals in the ${ }^{1} \mathrm{H}$ - and ${ }^{13} \mathrm{C}-\mathrm{NMR}$ spectra showed a ratio 2 and 3 in the mixture of approximately 1:1 for with a slight advantage of 2 .
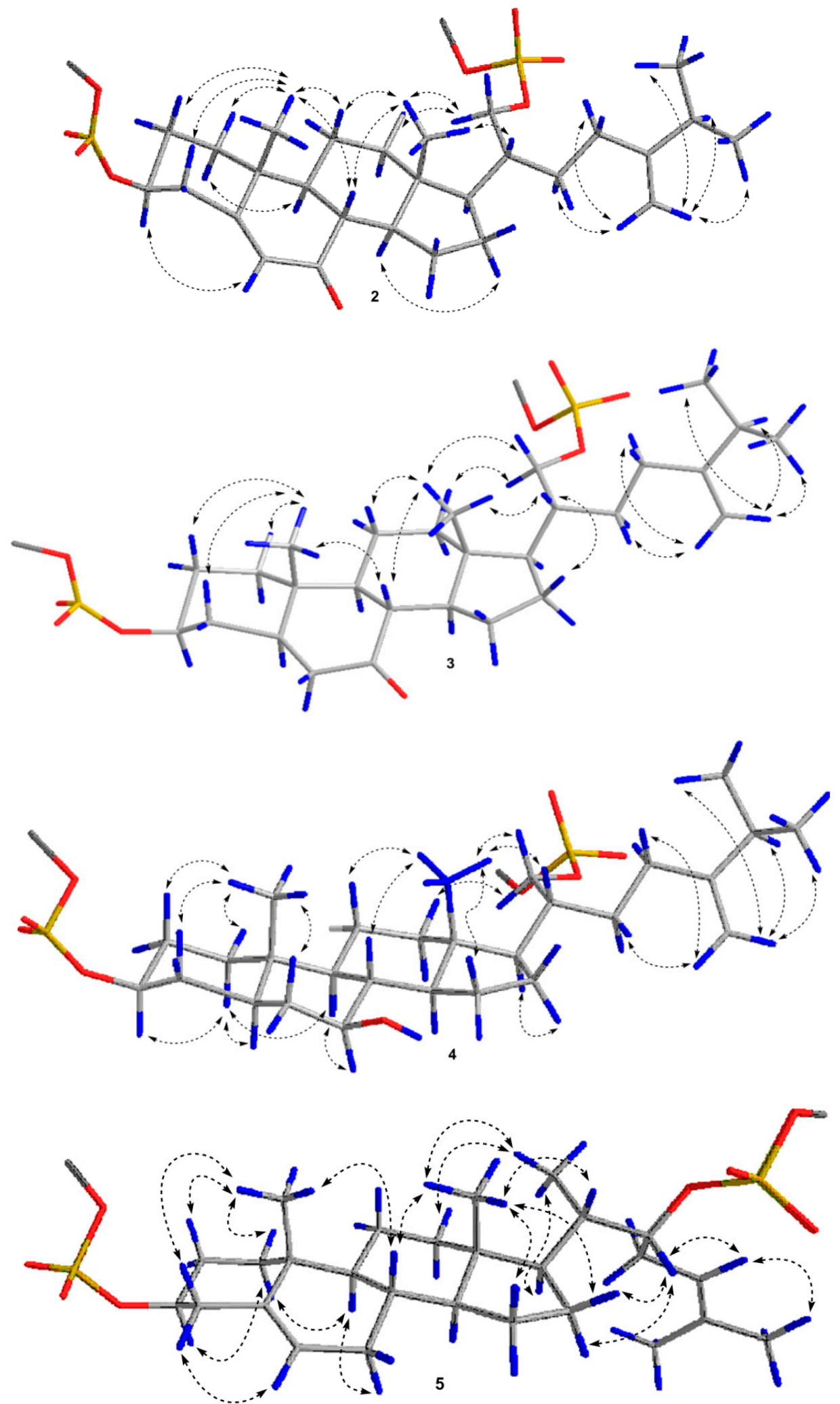

Figure 3. Key ROESY correlations for compounds 2-5. Colors reveal the atoms of hydrogen (blue), oxygen (red), sulfur (yellow), and carbon (grey) and their bonds. 
Solvolysis of the mixture of $\mathbf{2}$ and $\mathbf{3}$ in dioxane/pyridine afforded the mixture of desulfated derivatives $\mathbf{2 a}$ and $3 \mathbf{a}$, which were separated by HPLC on YMC-Pack-Pro C18 column to give individual compounds. The molecular formula of desulfated steroid $\mathbf{2 a}$ was established to be $\mathrm{C}_{28} \mathrm{H}_{44} \mathrm{O}_{3}$ from the $[\mathrm{M}-\mathrm{H}]^{-}$ion peak at $m / z 427.3215$ in the $(-)$ HRESIMS and from the $[\mathrm{M}+\mathrm{Na}]^{+}$sodium adduct ion peak at $m / z 451.3175$ in the $(+)$ HRESIMS, respectively (Figure S15). Along with mass spectra, the presence of the proton and carbon signals characteristic of two angular methyl groups $\mathrm{CH}_{3}-18\left(\delta_{\mathrm{H}} 0.73 \mathrm{~s}\right.$, $\left.\delta_{\mathrm{C}} 12.7\right)$ and $\mathrm{CH}_{3}-19\left(\delta_{\mathrm{H}} 1.23 \mathrm{~s}, \delta_{\mathrm{C}} 17.8\right)$, an oxygenated methine $\mathrm{CH}-3\left(\delta_{\mathrm{H}} 3.54 \mathrm{~m}, \delta_{\mathrm{C}} 71.2\right)$, a 5(6) double bond [ $\delta_{\mathrm{H}} 5.65 \mathrm{~m} ; \delta_{\mathrm{C}} 169.1,126.3$ ], a 7-oxo group $\left(\delta_{\mathrm{C}} 204.6\right)$, an oxygenated methylene $\mathrm{CH}_{2}-21\left[\delta_{\mathrm{H}} 3.69 \mathrm{dd}(J=10.7,4.2), 3.54 \mathrm{dd}(J=10.7,5.5) ; \delta_{\mathrm{C}} 63.2\right]$, and a $24(28)$ double bond $\left[\delta_{\mathrm{H}} 4.73 \mathrm{br} \mathrm{s}, 4.69 \mathrm{brd}(J=1.4) ; \delta_{\mathrm{C}} 157.8,106.9\right]$, two secondary methyls $\mathrm{CH}_{3}-26$ $\left[\delta_{\mathrm{H}} 1.03 \mathrm{~d}(J=6.8) ; \delta_{\mathrm{C}} 22.5\right]$ and $\mathrm{CH}_{3}-27\left[\delta_{\mathrm{H}} 1.03 \mathrm{~d}(J=6.8) ; \delta_{\mathrm{C}} 22.3\right]$ in the ${ }^{1} \mathrm{H}-$ and ${ }^{13} \mathrm{C}-\mathrm{NMR}$ spectra revealed the structure of $2 \mathbf{a}$ as (20R)-7-oxo-24-methylcholesta-5,24(28)-diene-3 $\beta, 21$ diol. The molecular formula of desulfated steroid $3 \mathbf{a}$ was established to be $\mathrm{C}_{28} \mathrm{H}_{46} \mathrm{O}_{3}$ from the $[\mathrm{M}-\mathrm{H}]^{-}$ion peak at $m / z 429.3376$ in the $(-)$ HRESIMS and from the $[\mathrm{M}+\mathrm{Na}]^{+}$sodium adduct ion peak at $m / z 453.3333$ in the (+)HRESIMS, respectively (Figure S16). The ${ }^{1} \mathrm{H}$ - and ${ }^{13} \mathrm{C}$-NMR spectra of 3 a contained signals for two angular methyl groups $\mathrm{CH}_{3}-18\left(\delta_{\mathrm{H}} 0.70 \mathrm{~s}\right.$, $\left.\delta_{\mathrm{C}} 12.8\right)$ and $\mathrm{CH}_{3}-19\left(\delta_{\mathrm{H}} 1.11 \mathrm{~s}, \delta_{\mathrm{C}} 12.1\right)$, an oxygenated methine $\mathrm{CH}-3\left(\delta_{\mathrm{H}} 3.52 \mathrm{~m}, \delta_{\mathrm{C}} 71.3\right)$, a 7-oxo group $\left(\delta_{\mathrm{C}} 214.4\right)$, an oxygenated methylene $\mathrm{CH}_{2}-21\left[\delta_{\mathrm{H}} 3.68 \mathrm{dd}(J=10.9,3.8), 3.53 \mathrm{dd}\right.$ $\left.(J=10.9,5.6) ; \delta_{\mathrm{C}} 63.2\right]$, and a $24(28)$ double bond $\left[\delta_{\mathrm{H}} 4.72 \mathrm{br} \mathrm{s}, 4.68 \mathrm{br} \mathrm{d}(J=1.4) ; \delta_{\mathrm{C}} 157.5\right.$, 106.9], two secondary methyls $\mathrm{CH}_{3}-26\left[\delta_{\mathrm{H}} 1.03 \mathrm{~d}(J=6.7) ; \delta_{\mathrm{C}} 22.5\right]$ and $\mathrm{CH}_{3}-27\left[\delta_{\mathrm{H}} 1.03 \mathrm{~d}\right.$ $\left.(J=6.7) ; \delta_{\mathrm{C}} 22.3\right]$ that matched structure $3 \mathbf{a}$ as (20R)-7-oxo-24-methyl-5 $\alpha$-cholest-24(28)-ene$3 \beta, 21$-diol. All the proton and carbon signals belonging to $2 \mathbf{a}$ and $3 \mathbf{a}$ were derived from COSY, HSQC, HMBC, and ROESY experiments (Table 3, Figures S17-S29). The isolation of individual desulfated derivatives $2 \mathbf{a}$ and $3 \mathbf{a}$ additionally confirmed the structures of steroids 2 and 3.

The molecular formula of steroid 4 was established to be $\mathrm{C}_{28} \mathrm{H}_{46} \mathrm{Na}_{2} \mathrm{O}_{9} \mathrm{~S}_{2}$ from the $[\mathrm{M}-\mathrm{Na}]^{-}$and $[\mathrm{M}-2 \mathrm{Na}]^{2-}$ ion peaks at $m / z 613.2483$ and $m / z 295.1304$ in the $(-)$ HRESIMS, respectively, and from the $[\mathrm{M}+\mathrm{Na}]^{+}$sodium adduct ion peak at $\mathrm{m} / z$ 659.2243 in the (+)HRESIMS (Figure S30). The presence of sulfate groups in 4 is confirmed by HRESIMS as well as by the presence in the (-)HRESIMS/MS spectrum of $[\mathrm{M}-2 \mathrm{Na}]^{2-}$ of fragment ions at $m / z 96.9604\left[\mathrm{HSO}_{4}\right]^{-}, 136.9909\left[\mathrm{C}_{3} \mathrm{H}_{5} \mathrm{O}_{4} \mathrm{~S}\right]^{-}, 191.0380\left[\mathrm{C}_{7} \mathrm{H}_{11} \mathrm{O}_{4} \mathrm{~S}\right]^{-}$, 409.2047 [M - Na $\left.-\mathrm{NaHSO}_{4}-\mathrm{C}_{6} \mathrm{H}_{12}\right]$, and $493.2987\left[\mathrm{M}-\mathrm{Na}-\mathrm{NaHSO}_{4}\right]^{-}$. The detailed comparison of the ${ }^{1} \mathrm{H}$ - and ${ }^{13} \mathrm{C}-\mathrm{NMR}$ spectroscopic data of compounds 4 and 3 revealed that the proton and carbon resonances belonging to the steroidal $\mathrm{A}, \mathrm{C}$, and D rings and side chains of 4 are close to those of 3 , indicating the $3 \beta$-hydroxy substitution in tetracyclic nucleus and $\Delta^{24(28)}$-21-sulfoxy-24-methyl-cholestane side chain in 4 , while the proton and carbon signals of the steroid B ring of 4 substantially differed from those of 3 (Tables 1 and 2, Figures S31 and S32). The absence of a carbon signal of the oxo group in the ${ }^{13} \mathrm{C}$-NMR spectrum of 4 in comparison with the ${ }^{13} \mathrm{C}-\mathrm{NMR}$ spectrum of 3 and the appearance of a triplet of doublets at $\delta_{\mathrm{H}} 3.25(J=10.6,5.2)$ in the ${ }^{1} \mathrm{H}-\mathrm{NMR}$ spectrum of 4 in comparison with the ${ }^{1} \mathrm{H}-\mathrm{NMR}$ spectrum of 3 indicated the presence of a hydroxyl function in the ring $\mathrm{B}$. The attachment of the hydroxyl group at $\mathrm{C}-7$ was deduced from proton and carbon correlations in the COSY, HSQC, and HMBC spectra (Figure 2 and Figures S33-S35). The key ROESY cross-peaks H $\alpha-1 / \mathrm{H}-3, \mathrm{H}-5, \mathrm{H}-9$; H-7 /H-9; $\mathrm{H} \beta-12 / \mathrm{H}_{2}-21 ; \mathrm{H} \alpha-16 / \mathrm{H}-17$; $\mathrm{H}_{3}-18 / \mathrm{H}-8, \mathrm{H} \beta-11, \mathrm{H} \beta-15, \mathrm{H}-20, \mathrm{H}_{2}-21$; and $\mathrm{H}_{3}-19 / \mathrm{H} \beta-1, \mathrm{H} \beta-2, \mathrm{H} \beta-4, \mathrm{H} \beta-6$; broad signal of H-3 and coupling constant $J=10.6 \mathrm{~Hz}$ of the triplet of doublets of axial proton H-7 confirmed the $3 \beta, 7 \beta$ relative configurations of the oxygenated carbons in the $\Delta^{24(28)}-24$ methyl-5 $\alpha$-cholestane skeleton in 4 (Figure 3 and Figure S36). As a result, the structure of 4 was established as (20R)-24-methyl-7 $\beta$-hydroxy- $5 \alpha$-cholest-24(28)-ene-3 $\beta, 21$-diyl disulfate disodium salt. 
Table 3. ${ }^{1} \mathrm{H}-(700.13 \mathrm{MHz})$ and ${ }^{13} \mathrm{C}-(176.04 \mathrm{MHz}) \mathrm{NMR}$ chemical shifts of compounds $\mathbf{2 a}$ and $3 \mathbf{a}$ in $\mathrm{CD}_{3} \mathrm{OD}$, with $\delta$ in ppm and $J$ values in $\mathrm{Hz}^{a}$.

\begin{tabular}{|c|c|c|c|c|}
\hline \multirow[t]{2}{*}{ Position } & \multicolumn{2}{|l|}{$2 a$} & \multicolumn{2}{|l|}{$3 a$} \\
\hline & $\delta_{\mathbf{H}}$ & $\delta_{\mathrm{C}}$ & $\delta_{\mathbf{H}}$ & $\delta_{\mathrm{C}}$ \\
\hline $1 \beta$ & $1.98 \mathrm{~m}$ & \multirow{2}{*}{37.6} & $1.77 \mathrm{~m}$ & \multirow{2}{*}{37.3} \\
\hline$\alpha$ & $1.22 \mathrm{~m}$ & & $1.03 \mathrm{~m}$ & \\
\hline $2 \alpha$ & $1.89 \mathrm{~m}$ & \multirow{2}{*}{31.9} & $1.80 \mathrm{~m}$ & \multirow{2}{*}{31.8} \\
\hline$\beta$ & $1.61 \mathrm{~m}$ & & $1.46 \mathrm{~m}$ & \\
\hline 3 & $3.54 \mathrm{~m}$ & 71.2 & $3.52 \mathrm{~m}$ & 71.3 \\
\hline $4 \alpha$ & $2.48 \mathrm{ddd}(13.5,4.6,2.1)$ & \multirow{2}{*}{42.8} & $1.56 \mathrm{~m}$ & \multirow{2}{*}{48.4} \\
\hline$\beta$ & $2.39 \mathrm{ddd}(13.5,11.5,2.0)$ & & $1.44 \mathrm{~m}$ & \\
\hline 5 & - & 169.1 & $1.48 \mathrm{~m}$ & 169.1 \\
\hline \multirow{2}{*}{6} & \multirow{2}{*}{$5.65 \mathrm{~m}$} & \multirow{2}{*}{126.3} & $2.45 \mathrm{t}(13.0)$ & \multirow{2}{*}{47.0} \\
\hline & & & $1.92 \mathrm{dd}(13.0,3.2)$ & \\
\hline 7 & - & 204.6 & - & 214.4 \\
\hline 8 & $2.31 \mathrm{dd}(12.8,10.8)$ & 46.6 & $2.47 \mathrm{t}(12.1)$ & 51.1 \\
\hline 9 & $1.51 \mathrm{~m}$ & 51.6 & $1.08 \mathrm{~m}$ & 57.0 \\
\hline 10 & - & 39.7 & - & 37.2 \\
\hline \multirow{2}{*}{11} & \multirow{2}{*}{$1.64 \mathrm{~m}$} & \multirow{2}{*}{22.3} & $1.62 \mathrm{~m}$ & \multirow{2}{*}{22.9} \\
\hline & & & $1.56 \mathrm{~m}$ & \\
\hline $12 \beta$ & $1.97 \mathrm{~m}$ & \multirow{2}{*}{39.3} & $1.92 \mathrm{~m}$ & \multirow{2}{*}{39.4} \\
\hline$\alpha$ & $1.19 \mathrm{~m}$ & & $1.14 \mathrm{~m}$ & \\
\hline 13 & - & 44.2 & - & 43.6 \\
\hline 14 & $1.32 \mathrm{~m}$ & 51.3 & $1.40 \mathrm{~m}$ & 50.4 \\
\hline $15 \alpha$ & $2.39 \mathrm{~m}$ & \multirow{2}{*}{27.3} & $2.19 \mathrm{~m}$ & \multirow{2}{*}{25.9} \\
\hline$\beta$ & $1.28 \mathrm{~m}$ & & $1.01 \mathrm{~m}$ & \\
\hline $16 \alpha$ & $1.87 \mathrm{~m}$ & \multirow{2}{*}{28.4} & $1.86 \mathrm{~m}$ & \multirow{2}{*}{28.4} \\
\hline$\beta$ & $1.39 \mathrm{~m}$ & & $1.37 \mathrm{~m}$ & \\
\hline 17 & $1.45 \mathrm{~m}$ & 50.6 & $1.45 \mathrm{~m}$ & 50.9 \\
\hline 18 & $0.73 \mathrm{~s}$ & 12.7 & $0.70 \mathrm{~s}$ & 12.8 \\
\hline 19 & $1.23 \mathrm{~s}$ & 17.8 & $1.11 \mathrm{~s}$ & 12.1 \\
\hline 20 & $1.51 \mathrm{~m}$ & 43.2 & $1.50 \mathrm{~m}$ & 43.2 \\
\hline \multirow{2}{*}{21} & $3.69 \mathrm{dd}(10.7,4.2)$ & \multirow{2}{*}{63.2} & $3.68 \mathrm{dd}(10.9,3.8)$ & \multirow{2}{*}{63.2} \\
\hline & $3.54 \mathrm{dd}(10.7,5.5)$ & & $3.53 \mathrm{dd}(10.9,5.6)$ & \\
\hline 22 & $1.63 \mathrm{~m}$ & 294 & $1.61 \mathrm{~m}$ & 293 \\
\hline & $1.44 \mathrm{~m}$ & & $1.43 \mathrm{~m}$ & \\
\hline 23 & $2.15 \mathrm{~m}$ & 323 & $2.13 \mathrm{~m}$ & 323 \\
\hline & $1.98 \mathrm{~m}$ & & $1.97 \mathrm{~m}$ & \\
\hline 24 & - & 157.8 & - & 157.5 \\
\hline 25 & 2.25 quin & 34.9 & 2.25 quin & 34.9 \\
\hline 26 & $1.03 \mathrm{~d}(6.8)$ & 22.5 & $1.03 \mathrm{~d}(6.7)$ & 22.5 \\
\hline 27 & $1.03 \mathrm{~d}(6.8)$ & 22.3 & $1.03 \mathrm{~d}(6.7)$ & 22.3 \\
\hline 28 & $\begin{array}{c}4.73 \text { br s } \\
4.69 \text { br d (1.4) }\end{array}$ & 106.9 & $\begin{array}{c}4.72 \text { br s } \\
4.68 \text { br d }(1.4)\end{array}$ & 106.9 \\
\hline
\end{tabular}

${ }^{a}$ Assignments from $700.13 \mathrm{MHz}$ COSY, HSQC, HMBC (8 Hz), and ROESY (250 msec) data.

The molecular formula of steroid 5 was established to be $\mathrm{C}_{27} \mathrm{H}_{42} \mathrm{Na}_{2} \mathrm{O}_{8} \mathrm{~S}_{2}$ from the $[\mathrm{M}-\mathrm{Na}]^{-}$and $[\mathrm{M}-2 \mathrm{Na}]^{2-}$ ion peaks at $m / z 581.2216$ and $m / z 279.1171$ in the 
(-)HRESIMS, respectively, and from the $[\mathrm{M}+\mathrm{Na}]^{+}$sodium adduct ion peak at $\mathrm{m} / z 627.1993$ in the (+)HRESIMS (Figure S37). The presence of sulfate groups in 5 is confirmed by HRESIMS as well as by the presence in the (-)HRESIMS/MS spectrum of $[\mathrm{M}-2 \mathrm{Na}]^{2-}$ of fragment ions at $m / z 96.9601\left[\mathrm{HSO}_{4}\right]^{-}, 409.2041\left[\mathrm{M}-\mathrm{Na}-\mathrm{NaHSO}_{4}-\mathrm{C}_{5} \mathrm{H}_{8}\right]^{-}$, and 461.2722 [M - Na - $\left.\mathrm{NaHSO}_{4}\right]^{-}$. The examination of the ${ }^{1} \mathrm{H}-{ }^{13} \mathrm{C}_{-}$, and 2D NMR spectra of 5 and 1 revealed that both compounds have the identical $\Delta^{5(6)}-3 \beta$-sulfoxy tetracyclic moiety, but the proton and carbon resonances of the steroid side chain of $\mathbf{5}$ differed from those of $\mathbf{1}$ (Tables 1 and 2, Figures S38-S43). The proton and carbon signals in the ${ }^{1} \mathrm{H}$ - and ${ }^{13} \mathrm{C}-\mathrm{NMR}$ spectra belonging to the side chain of 1 showed the presence of three methyls $\mathrm{CH}_{3}-21$ $\left[\delta_{\mathrm{H}} 0.96 \mathrm{~d}(J=6.7) ; \delta_{\mathrm{C}} 12.8\right], \mathrm{CH}_{3}-26\left(\delta_{\mathrm{H}} 1.69 \mathrm{~s} ; \delta_{\mathrm{C}} 26.0\right)$, and $\mathrm{CH}_{3}-27\left(\delta_{\mathrm{H}} 1.65 \mathrm{~s} ; \delta_{\mathrm{C}} 18.1\right)$, an oxygenated methine $\mathrm{CH}-22\left[\delta_{\mathrm{H}} 4.36 \mathrm{dd}(J=10.6,4.5) ; \delta_{\mathrm{C}} 82.6\right]$, and the 24-double bond $\left[\delta_{\mathrm{H}} 5.05 \mathrm{t}(J=7.7) ; \delta_{\mathrm{C}} 121.2,134.8\right]$. The proton connectivities from C-21 through C-20 to C-24 in the side chain were ascertained using the COSY and HSQC experiments. The attachment of the sulfoxy group at $\mathrm{C}-22$ and a 24-double bond were supported from the HMBC cross-peaks $\mathrm{H}_{3}-21$ /C-17, C-20, C-22; H-22/C-17, C-20, C-24; H-23/C-24, C-25; $\mathrm{H}_{3}-26 / \mathrm{C}-24, \mathrm{C}-25$; and $\mathrm{H}_{3}-27 / \mathrm{C}-24, \mathrm{C}-25$ (Figure 2). The $20 \mathrm{~S}$ configuration was elucidated by the ROESY correlations of $\mathrm{H} \beta-12 / \mathrm{H}-20, \mathrm{H}-17 / \mathrm{H}_{3}-21$, and $\mathrm{H}_{3}-18 / \mathrm{H}-20, \mathrm{H}_{3}-21$, and the downfield chemical shift of $\mathrm{H}_{3}-21$ at $\delta_{\mathrm{H}} 0.96$ [21,23-25]. Based on the $20 S$ configuration, we suggested the $22 \mathrm{R}$ configuration because the ROESY correlations of $\mathrm{H}-22 / \mathrm{H}_{2}-16$ were observed (Figure 3). Similar correlations were observed in the NOEs spectrum of a natural

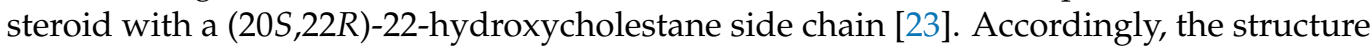
of 5 was elucidated as (20S)-cholesta-5,24-diene-3 $\beta, 22$-diyl disulfate disodium salt. The $\Delta^{24}$-22-sulfoxycholestane side chain of the compound 5 has not been known earlier in other starfish or ophiuroid steroids. It's interesting that the desulfated derivative $(20 S, 22 R)$ cholesta-5,24-diene-3 $\beta, 22$-diol or $22 R$-hydroxydesmosterol, related to compound 5 , is a derivative of desmosterol, a biosynthetic precursor of cholesterol. 22R-Hydroxydesmosterol was earlier obtained by stereospecific synthesis and shown to have a cytotoxic effect on tumor and hepatoma cells [26,27].

Previously reported feeding experiments labeled with deuterium precursors have shown that polyhydroxysteroids and related steroidal glycosides of starfish are biosynthesized from dietary cholesterol and cholesterol sulfate [28]. Obviously, the precursors of the biosynthesis of steroidal disulfates 1-5 are presumably cholesterol or cholesterol sulfate. The biosynthesis of these compounds takes place with the participation of enzymatic systems such as oxygenases, NAD and NADP-dependent dehydrogenases, SAMmethyltransferase, etc. The following hypothetical pathways for the biosynthesis of compounds $\mathbf{2} \mathbf{- 4}$ are proposed. Compound $\mathbf{1}$ undergoes changes only in the steroidal side chain in comparison with cholesterol sulfate by oxidation at $\mathrm{CH}_{3}-21$ followed by sulfation and introduction of a methylene group by SAM-methyltransferase at C-24 with loss of a proton. The introduction of a hydroxyl group at $\mathrm{C}-7$ of ring $\mathrm{B}$ of the steroidal nucleus of $\mathbf{1}$ gives an intermediate. Oxidation of the hydroxyl group at C-7 in the intermediate leads to the formation of steroid disulfate 2 , and reduction of the 5(6)-double bond leads to the formation of 4 . The end product, obviously, is the steroid disulfate 3 , which can be obtained from both compounds 2 and 4 (by oxidation or reduction). In compound 5 , as well as in 1, there are no changes in the steroid nucleus, and only the side chain is modified by oxidation with the following sulfation at the $\mathrm{C}-22$ position.

\subsection{In Vitro Anticancer Activity of Compounds 1-5}

Currently, the main cellular model of cell biology is a two-dimensional (2D) monolayer. However, the cell growth in a monolayer does not reflect the true picture of tumor growth in a living organism by many parameters, where interactions not only between the cells of the tumor but also with the surrounding extracellular matrix are of great importance in its progression. The three-dimensional (3D cell culture) model is represented by spheroids, and proved to be the most effective system that is as close as possible in properties and organization to a natural tumor, which is used for screening the potential anticancer 
A

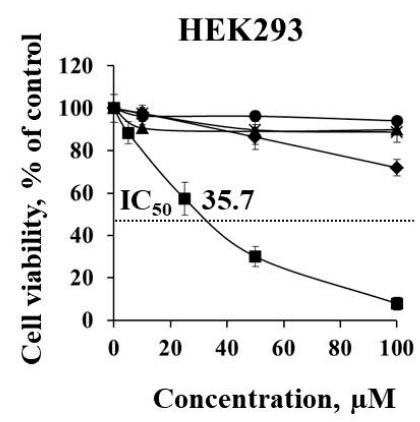

drugs [29]. So, the cytotoxic activity of $\mathbf{1}, \mathbf{4}$, and $\mathbf{5}$ and the mixture of $\mathbf{2}$ and $\mathbf{3}$ was determined on the models of 2D and 3D cultures of human epithelial kidney cells (HEK293), melanoma cells (SK-MEL-28), small intestine carcinoma cells (HuTu80), and breast carcinoma cells (ZR-75-1) using the MTS method.

The investigated compounds $\mathbf{1 - 5}$ were determined to possess moderate cytotoxic activity against normal and cancer cells with the greater impact of the mixture of $\mathbf{2}$ and 3. It was found that this mixture inhibited the cell viability of 2D HEK293, SK-MEL-28, HuTu80, and ZR-75-1 by 28, 33, 34, and 55\%, respectively, at a concentration of $100 \mu \mathrm{M}$ after $24 \mathrm{~h}$ of treatment (Figure $4 \mathrm{~A}-\mathrm{D}$ ). The concentration of the mixture of $\mathbf{2}$ and $\mathbf{3}$, which caused inhibition of $50 \%$ cell viability $\left(\mathrm{IC}_{50}\right)$ was established against more sensitive breast carcinoma cells ZR-75-1 as $90.4 \mu \mathrm{M}$ (Figure $4 \mathrm{D}$ ). The $\mathrm{IC}_{50}$ of doxorubicin (Doxo), used as a positive control, was 35.7, 40.0, 11.2, and 19.2 $\mu$ M against 2D HEK293, SK-MEL-28, HuTu80, and ZR-75-1, respectively (Figure 4A-D).
B

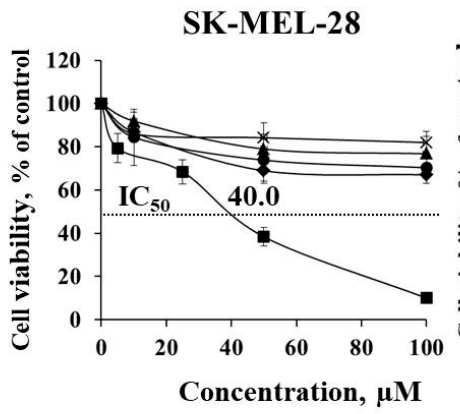

$\rightarrow-D o x o$
C

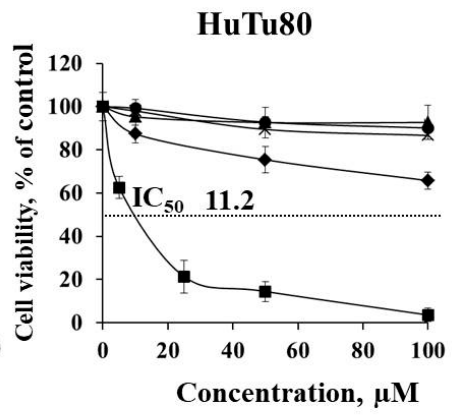

D

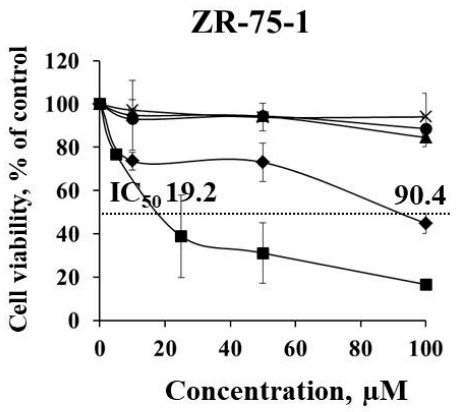

Figure 4. The cytotoxic effect of compounds 1-5 on the model of 2D (A) HEK293, (B) SK-MEL-28, (C) HuTu80, and (D) ZR-75-1 cells. Cells monolayer was treated with Doxo at concentrations of 5, 25,50 , and $100 \mu \mathrm{M}$ or $\mathbf{1}, 4$, and 5 and the mixture of 2 and 3 at concentrations of 10,50 , and 100 $\mu \mathrm{M}$ and incubated for $24 \mathrm{~h}$. Cell viability was assessed using the MTS test. Data are presented as means \pm standard deviation, as determined in three experiments.

The investigated compounds insignificantly affect the size of the spheroids but inhibit their viability to varying degrees (Figure 5A-C). It was determined that the mixture of 2 and 3 inhibited viability of SK-MEL-28, HuTu80, and ZR-75-1 spheroids by 16, 36, and 51\%, respectively, at $100 \mu \mathrm{M}$ after $24 \mathrm{~h}$ of treatment. As in the case of 2D culture cells, ZR-75-1 spheroids were the most sensitive to the cytotoxic action of the mixture of 2 and $3 . \mathrm{IC}_{50}$ of Doxo was $30.9 \mu \mathrm{M}$ and $21.9 \mu \mathrm{M}$ against HuTu80 and ZR-75-1, respectively.

It should be noted that 3D cell cultures were more resistant to the action of compounds than $2 \mathrm{D}$ cultures, which can be explained by dynamic cellular interactions between neighboring cells in spheroids. Moreover, the increased resistance of 3D spheroids may be associated with limited diffusion of the tested substances into the spheroid and hypoxia of cells within the spheroid, which leads to the activation of genes involved in cell survival and the formation of drug resistance [30].

In summary, the results of the present study described the significant inhibiting effect of the mixture of compounds $\mathbf{2}$ and $\mathbf{3}$ on the cell viability of human breast carcinoma cells ZR-75-1 in 2D and 3D cell culture models and may contribute to the development of effective chemotherapeutic methods for cancer treatment. 


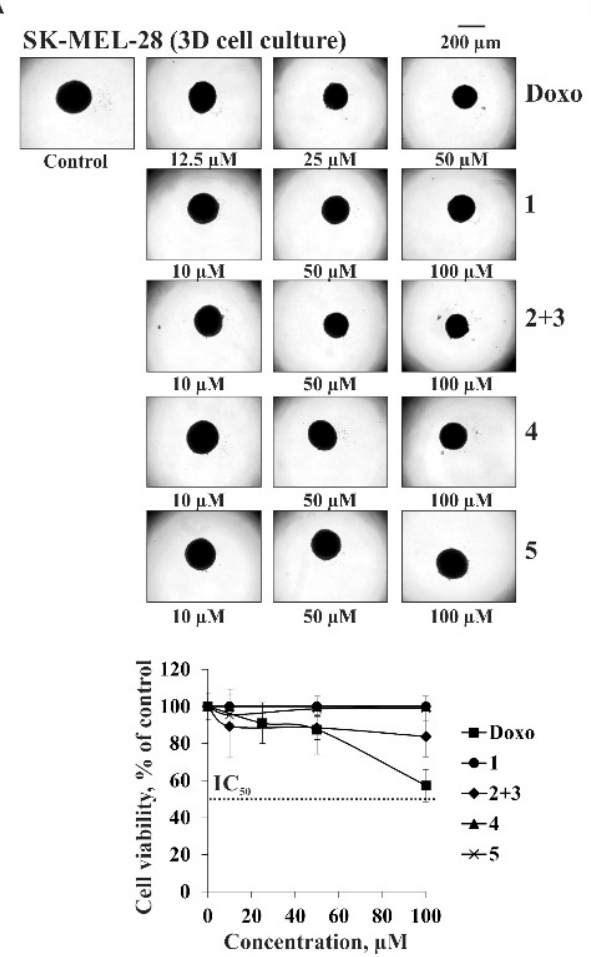

B
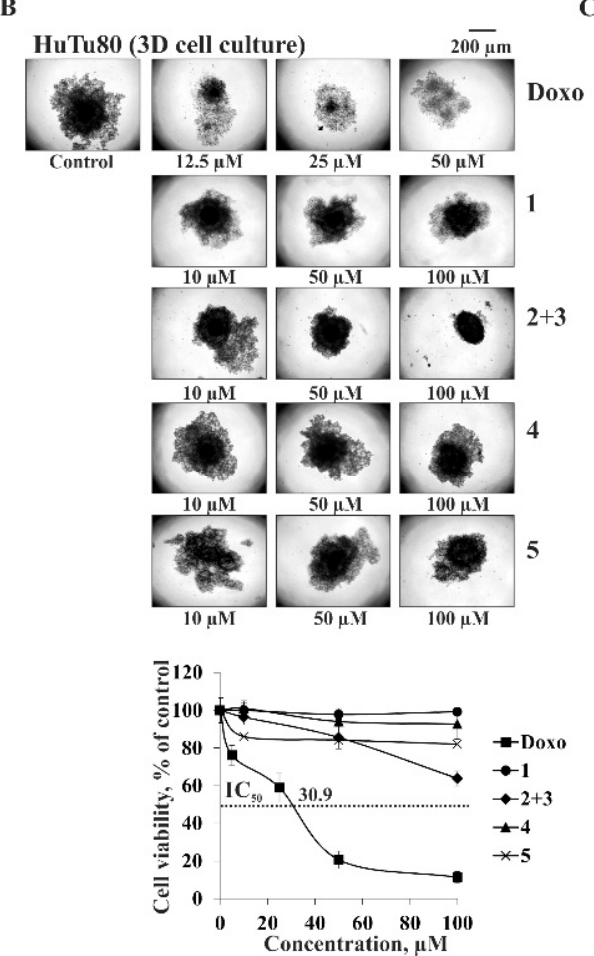

C
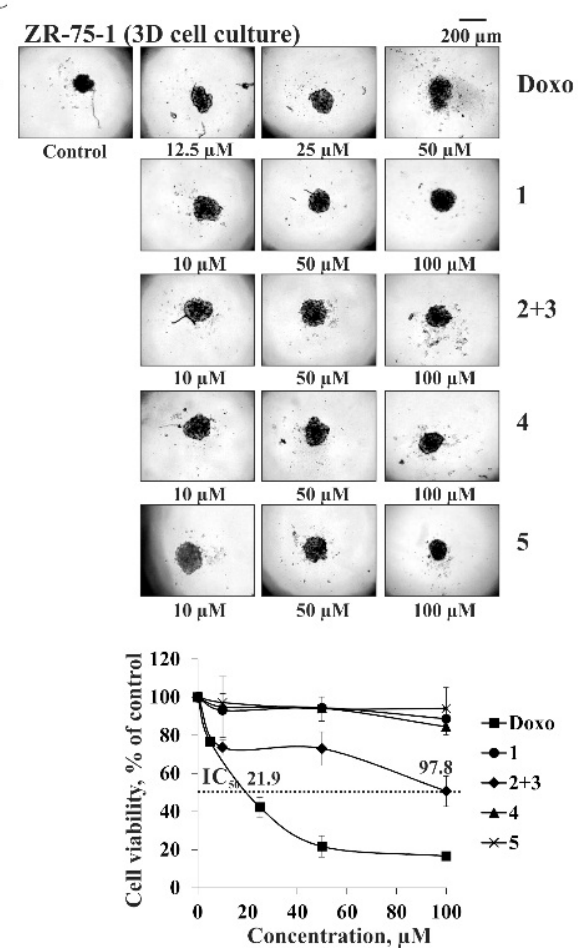

Figure 5. The cytotoxic effect of compounds 1-5 on the model of 3D (A) SK-MEL-28, (B) HuTu80, and (C) ZR-75-1 cells. Spheroids were treated with Doxo at concentrations of 5, 25, 50, and $100 \mu \mathrm{M}$ or 1,4 , and 5 and the mixture of 2 and 3 at concentrations of 10,50 , and $100 \mu \mathrm{M}$ and incubated for $24 \mathrm{~h}$. Cell viability was assessed using the MTS test. Data are presented as means \pm standard deviation, as determined in three experiments. Photographs ( $\mathrm{n}=6$ for controls or cells treated with polysaccharides or derivatives, where $\mathrm{n}=$ number of photographs) of each spheroid were taken with the ZOE TM Fluorescent Cell Imager. Spheroids were analyzed using ImageJ software.

\section{Materials and Methods}

\subsection{General Procedures}

Optical rotations were determined on a Perkin-Elmer 343 polarimeter (PerkinElmer, Waltham, MA, USA). The ${ }^{1} \mathrm{H}$ - and ${ }^{13} \mathrm{C}-\mathrm{NMR}$ spectra were recorded on a Bruker Avance III 700 spectrometer (Bruker BioSpin, Bremen, Germany) at 700.13 and $176.04 \mathrm{MHz}$, respectively. Chemical shifts (ppm) were internally referenced to the corresponding residual solvent signals at $\delta_{\mathrm{H}} 3.30 / \delta_{\mathrm{C}} 49.0$ for $\mathrm{CD}_{3} \mathrm{OD}$. HRESIMS mass spectra were recorded on a Bruker Impact II Q-TOF mass spectrometer (Bruker, Bremen, Germany); the samples were dissolved in $\mathrm{MeOH}$ (c $0.001 \mathrm{mg} / \mathrm{mL}$ ). HPLC separations were carried out on an Agilent 1100 Series chromatograph (Agilent Technologies, Santa Clara, CA, USA), equipped with a differential refractometer; Discovery C18 $(5 \mu \mathrm{m}, 250 \times 10 \mathrm{~mm}$, Supelco, Bellefonte, PA, USA) and YMC-Pack Pro C18 (5 m, $250 \times 4.6$ mm, YMC CO., LTD., Kyoto, Japan) columns were used. Low-pressure column liquid chromatography was performed using Polychrom 1 (powdered Teflon, 0.25-0.50 mm; Biolar, Olaine, Latvia) and silica gel

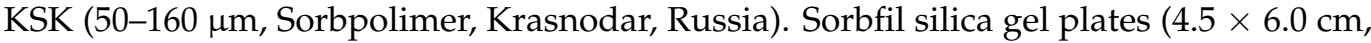
5-17 $\mu \mathrm{m}$, Sorbpolimer, Krasnodar, Russia) were used for thin-layer chromatography.

\subsection{Animal Material}

Specimens of Pteraster marsippus Fisher, 1910 (order Velatida, family Pterasteridae) were collected at a depth of 84-88 m using a small trawl off Urup Island in the Sea of Okhotsk (45.5280 N, 149.4230 E) during the research vessel Akademik Oparin 51th scientific cruise in May 2017. Species identification was carried out by Mr. B.B. Grebnev (G.B. Elyakov Pacific Institute of Bioorganic Chemistry of the FEB RAS, Vladivostok, Russia). A 
voucher specimen [no. 051-039] is on deposit at the marine specimen collection of the G.B. Elyakov Pacific Institute of Bioorganic Chemistry of the FEB RAS, Vladivostok, Russia.

\subsection{Extraction and Isolation}

Freshly collected specimens of $P$. marsippus were frozen and stored at $-21^{\circ} \mathrm{C}$ until used. The frozen animals $(2.1 \mathrm{~kg})$ were cut into small pieces and extracted twice with $\mathrm{EtOH}$ at room temperature $(2.0 \mathrm{~L} / \mathrm{kg})$. The extract was evaporated and the residue $(150 \mathrm{~g})$ was dissolved in $\mathrm{H}_{2} \mathrm{O}(1.0 \mathrm{~L})$. The $\mathrm{H}_{2} \mathrm{O}$-soluble fraction was passed through a Polychrom 1 column $(8 \times 62 \mathrm{~cm})$ and eluted with distilled $\mathrm{H}_{2} \mathrm{O}$ until a negative chloride ion reaction was obtained, followed by elution with $50 \%$ aq. $\mathrm{EtOH}$. The combined aq. EtOH eluate was evaporated to give a brownish residue $(6.0 \mathrm{~g})$. This fraction was chromatographed over a Si gel column $(6.5 \times 15 \mathrm{~cm})$ using $\mathrm{CHCl}_{3} / \mathrm{EtOH}$ (stepwise gradient, $4: 1$ to $\left.1: 2, v / v\right), \mathrm{EtOH}$, and $\mathrm{EtOH} / \mathrm{H}_{2} \mathrm{O}(9: 1, v / v)$ and rechromatographed over a Florisil column $(7 \times 15 \mathrm{~cm})$ using $\mathrm{CHCl}_{3} / \mathrm{EtOH}$ (stepwise gradient, 2:1 to 1:1, $v / v$ ) to yield eleven main fractions (1-11) that were analyzed by TLC on Si gel plates in the eluent systems toluene/EtOH $(9: 5, v / v)$ and $\mathrm{n}-\mathrm{BuOH} / \mathrm{EtOH} / \mathrm{H}_{2} \mathrm{O}(4: 1: 2, v / v / v)$. Fractions 5 and 7 contained the mixtures of disulfated steroids. HPLC separation of fraction 5 (194 mg) on a Discovery C18 column with $54 \%$ aq. $\mathrm{EtOH}(2.0 \mathrm{~mL} / \mathrm{min})$ as an eluent system followed by the further separation on the same column with $62 \%$ aq. $\mathrm{MeOH}(2.0 \mathrm{~mL} / \mathrm{min})$ as an eluent system yielded pure $\mathbf{1}(1.1 \mathrm{mg}$, $\left.t_{\mathrm{R}} 18.8 \mathrm{~min}\right)$. HPLC separation of fraction $7(297 \mathrm{mg})$ on a Discovery C18 column with $60 \%$ aq. $\mathrm{MeOH}(2.0 \mathrm{~mL} / \mathrm{min})$ as an eluent system followed by the further separation on a YMC-Pack Pro C18 column with $60 \%$ aq. $\mathrm{MeOH}(0.6 \mathrm{~mL} / \mathrm{min})$ as an eluent system gave the mixture of 2 and $3\left(16.1 \mathrm{mg}, t_{\mathrm{R}} 12.8 \mathrm{~min}\right)$, pure $4\left(2.3 \mathrm{mg}, t_{\mathrm{R}} 8.5 \mathrm{~min}\right)$ and $5(1.5 \mathrm{mg}$, $\left.t_{\mathrm{R}} 16.5 \mathrm{~min}\right)$.

\subsection{Compound Characterization Data}

(20R)-24-Methylcholesta-5,24(28)-diene-3 3,21 -diyl disulfate disodium salt (1): Colorless amorphous powder; $[\alpha]_{\mathrm{D}}^{25}$ : $-14.5\left(c\right.$ 0.11, MeOH); $(-)$ HRESIMS $m / z 595.2388[\mathrm{M}-\mathrm{Na}]^{-}$ (calcd for $\mathrm{C}_{28} \mathrm{H}_{44} \mathrm{NaO}_{8} \mathrm{~S}_{2}, 595.2381$ ); (-)HRESIMS $m / z$ 286.1253 [M - 2Na] ${ }^{-}$(calcd for $\mathrm{C}_{28} \mathrm{H}_{44} \mathrm{O}_{8} \mathrm{~S}_{2}, 286.1244$ ); (+)HRESIMS $m / z 641.2154$ [M + Na] ${ }^{+}$(calcd for $\mathrm{C}_{28} \mathrm{H}_{44} \mathrm{Na}_{3} \mathrm{O}_{8} \mathrm{~S}_{2}$, 641.2165); HRESIMS/MS of the [M - 2Na] $]^{2-}$ ion at $m / z$ 286.1253: $475.2898[\mathrm{M}-\mathrm{Na}-$ $\left.\mathrm{NaHSO}_{4}\right]^{-}, 459.2584\left[\mathrm{M}-\mathrm{Na}-\mathrm{NaHSO}_{4}-\mathrm{CH}_{4}\right]^{-}, 391.1958\left[\mathrm{M}-\mathrm{Na}-\mathrm{NaHSO}_{4}-\mathrm{C}_{6} \mathrm{H}_{12}\right]^{-}$, $136.9917\left[\mathrm{C}_{3} \mathrm{H}_{5} \mathrm{O}_{4} \mathrm{~S}\right]^{-}, 96.9610\left[\mathrm{HSO}_{4}\right]^{-} ;{ }^{1} \mathrm{H}-\mathrm{NMR}$ data (see Table 1 ); ${ }^{13} \mathrm{C}-\mathrm{NMR}$ data (see Table 2).

(20R)-7-Oxo-24-methylcholesta-5,24(28)-diene-3ß,21-diyl disulfate disodium salt (2); Colorless amorphous powder; the mixture of 2 and $3[\alpha]_{\mathrm{D}}{ }^{25}$ : $-28.8(\mathrm{c} 0.82, \mathrm{MeOH})$; (-)HRESIMS $m / z$ 609.2177 [M - Na] ${ }^{-}$(calcd for $\mathrm{C}_{28} \mathrm{H}_{42} \mathrm{NaO}_{9} \mathrm{~S}_{2}, 609.2173$ ); (-)HRESIMS $\mathrm{m} / \mathrm{z} 293.1148[\mathrm{M}-2 \mathrm{Na}]^{2-}$ (calcd for $\mathrm{C}_{28} \mathrm{H}_{42} \mathrm{O}_{9} \mathrm{~S}_{2}, 293.1141$ ); (+)HRESIMS $\mathrm{m} / \mathrm{z}$ $655.1943[\mathrm{M}+\mathrm{Na}]^{+}$(calcd for $\mathrm{C}_{28} \mathrm{H}_{42} \mathrm{Na}_{3} \mathrm{O}_{9} \mathrm{~S}_{2}, 655.1958$ ); HRESIMS/MS of the [M $\left.-2 \mathrm{Na}\right]^{2-}$ ion at $m / z$ 293.1148: $489.2682\left[\mathrm{M}-\mathrm{Na}-\mathrm{NaHSO}_{4}\right]^{-}, 405.1745\left[\mathrm{M}-\mathrm{Na}-\mathrm{NaHSO}_{4}-\mathrm{C}_{6} \mathrm{H}_{12}\right]^{-}$, $136.9917\left[\mathrm{C}_{3} \mathrm{H}_{5} \mathrm{O}_{4} \mathrm{~S}\right]^{-}, 96.9612\left[\mathrm{HSO}_{4}\right]^{-} ;{ }^{1} \mathrm{H}-\mathrm{NMR}$ data (see Table 1$) ;{ }^{13} \mathrm{C}-\mathrm{NMR}$ data (see Table 2).

(20R)-7-Oxo-24-methyl-5 $\alpha$-cholest-24(28)-ene-3 $\beta, 21$-diyl disulfate disodium salt (3); Colorless amorphous powder; the mixture of 2 and $3[\alpha]_{\mathrm{D}}{ }^{25}$ : $-28.8(c 0.82, \mathrm{MeOH})$; (-)HRESIMS $m / z 611.2299$ [M - Na] ${ }^{-}$(calcd for $\mathrm{C}_{28} \mathrm{H}_{44} \mathrm{NaO}_{9} \mathrm{~S}_{2}, 611.2330$ ); (-)HRESIMS $m / z$ 294. $1222[\mathrm{M}-2 \mathrm{Na}]^{2-}$ (calcd for $\mathrm{C}_{28} \mathrm{H}_{44} \mathrm{O}_{9} \mathrm{~S}_{2}, 294.1219$ ); (+)HRESIMS $m / z 657.2077$ $\left[\mathrm{M}+\mathrm{Na}^{+}\right.$(calcd for $\left.\mathrm{C}_{28} \mathrm{H}_{44} \mathrm{Na}_{3} \mathrm{O}_{9} \mathrm{~S}_{2}, 657.2114\right) ; \mathrm{HRESIMS} / \mathrm{MS}$ of the $[\mathrm{M}-2 \mathrm{Na}]^{2-}$ ion at $m / z$ 294.1222: $491.2825\left[\mathrm{M}-\mathrm{Na}-\mathrm{NaHSO}_{4}\right]^{-}, 407.1891\left[\mathrm{M}-\mathrm{Na}-\mathrm{NaHSO}_{4}-\mathrm{C}_{6} \mathrm{H}_{12}\right]^{-}$, $136.9917\left[\mathrm{C}_{3} \mathrm{H}_{5} \mathrm{O}_{4} \mathrm{~S}\right]^{-}, 96.9612\left[\mathrm{HSO}_{4}\right]^{-} ;{ }^{1} \mathrm{H}-\mathrm{NMR}$ data (see Table 1$) ;{ }^{13} \mathrm{C}-\mathrm{NMR}$ data (see Table 2).

(20R)-24-Methyl-7 $\beta$-hydroxy-5 $\alpha$-cholest-24(28)-ene-3 $\beta, 21$-diyl disulfate disodium salt (4); Colorless amorphous powder; $[\alpha]_{\mathrm{D}}{ }^{25}:+9.6$ ( $\left.c 0.23, \mathrm{MeOH}\right) ;(-)$ HRESIMS $m / z 613.2483$

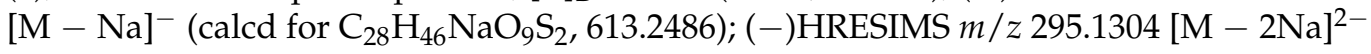
(calcd for $\mathrm{C}_{28} \mathrm{H}_{46} \mathrm{O}_{9} \mathrm{~S}_{2}, 295.1297$ ); (+)HRESIMS $m / z$ 659.2243 [M $\left.+\mathrm{Na}\right]^{+}$(calcd for 
$\left.\mathrm{C}_{28} \mathrm{H}_{46} \mathrm{Na}_{3} \mathrm{O}_{9} \mathrm{~S}_{2}, 659.2271\right) ; \mathrm{HRESIMS} / \mathrm{MS}$ of the $[\mathrm{M}-2 \mathrm{Na}]^{2-}$ ion at $m / z$ 295.1304: 493.2987 $\left[\mathrm{M}-\mathrm{Na}-\mathrm{NaHSO}_{4}\right]^{-}, 409.2047\left[\mathrm{M}-\mathrm{Na}-\mathrm{NaHSO}_{4}-\mathrm{C}_{6} \mathrm{H}_{12}\right], 191.0380\left[\mathrm{C}_{7} \mathrm{H}_{11} \mathrm{O}_{4} \mathrm{~S}\right]^{-}$, $136.9909\left[\mathrm{C}_{3} \mathrm{H}_{5} \mathrm{O}_{4} \mathrm{~S}\right]^{-}, 96.9604\left[\mathrm{HSO}_{4}\right]^{-} ;{ }^{1} \mathrm{H}-\mathrm{NMR}$ data (see Table 1 ); ${ }^{13} \mathrm{C}-\mathrm{NMR}$ data (see Table 2).

(20S)-Cholesta-5,24-diene-3 $\beta, 22$-diyl disulfate disodium salt (5); Colorless amorphous powder; $[\alpha]_{\mathrm{D}}{ }^{25}$ : -14.0 (c 0.15, MeOH); (-)HRESIMS $m / z$ 581.2216 [M - Na] $]^{-}$(calcd for $\mathrm{C}_{27} \mathrm{H}_{42} \mathrm{NaO}_{8} \mathrm{~S}_{2}, 581.2224$ ); (-)HRESIMS $m / z 279.1171[\mathrm{M}-2 \mathrm{Na}]^{2-}$ (calcd for $\mathrm{C}_{27} \mathrm{H}_{42} \mathrm{O}_{8} \mathrm{~S}_{2}$, 279.1166); (+)HRESIMS $m / z 627.1993[\mathrm{M}+\mathrm{Na}]^{+}$(calcd for $\mathrm{C}_{27} \mathrm{H}_{42} \mathrm{Na}_{3} \mathrm{O}_{8} \mathrm{~S}_{2}, 627.2009$ ); HRESIMS/MS of the $[\mathrm{M}-2 \mathrm{Na}]^{2-}$ ion at $m / z$ 279.1171: $461.2722\left[\mathrm{M}-\mathrm{Na}-\mathrm{NaHSO}_{4}\right]^{-}$, $409.2041\left[\mathrm{M}-\mathrm{Na}-\mathrm{NaHSO}_{4}-\mathrm{C}_{5} \mathrm{H}_{8}\right]^{-}, 96.9601\left[\mathrm{HSO}_{4}\right]^{-} .{ }^{1} \mathrm{H}-\mathrm{NMR}$ data (see Table 1); ${ }^{13} \mathrm{C}-\mathrm{NMR}$ data (see Table 2).

\subsection{Solvolysis of the Mixture of $\mathbf{2}$ and $\mathbf{3}$}

A solution of the mixture of 2 and $3(5.0 \mathrm{mg})$ in $2 \mathrm{~mL}$ of dioxane/pyridine (1:1) was heated at $100{ }^{\circ} \mathrm{C}$ for $4 \mathrm{~h}$. The reaction mixture was evaporated under reduced pressure and separated by HPLC on a YMC-Pack Pro C18 column with $80 \%$ aq. $\mathrm{MeOH}(0.7 \mathrm{~mL} / \mathrm{min})$ as an eluent system to give pure desulfated derivatives $\mathbf{2 a}\left(0.5 \mathrm{mg}, t_{\mathrm{R}} 40.6 \mathrm{~min}\right)$ and $\mathbf{3 a}$ $\left(0.4 \mathrm{mg}, t_{\mathrm{R}} 39.6 \mathrm{~min}\right)$.

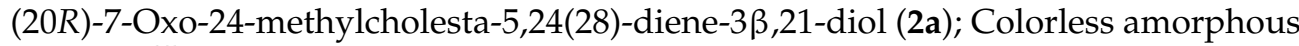
powder; $[\alpha]_{\mathrm{D}}{ }^{25}$ : -38.0 (c 0.05, MeOH); (-)HRESIMS $m / z$ 427.3215 $[\mathrm{M}-\mathrm{H}]^{-}$(calcd for $\mathrm{C}_{28} \mathrm{H}_{43} \mathrm{O}_{3}, 427.3218$ ); (+)HRESIMS $m / z 451.3175[\mathrm{M}+\mathrm{Na}]^{+}$(calcd for $\mathrm{C}_{28} \mathrm{H}_{44} \mathrm{NaO}_{3}$, 451.3183); ${ }^{1} \mathrm{H}$ - and ${ }^{13} \mathrm{C}-\mathrm{NMR}$ data (see Table 3 ).

(20R)-7-Oxo-24-methyl-5 $\alpha$-cholest-24(28)-ene-3 $\beta$,21-diol (3a); Colorless amorphous powder; $[\alpha]_{\mathrm{D}}^{25}$ : $-5.0($ c $0.04, \mathrm{MeOH}) ;(-)$ HRESIMS $m / z 429.3376[\mathrm{M}-\mathrm{H}]^{-}$(calcd for $\mathrm{C}_{28} \mathrm{H}_{45} \mathrm{O}_{3}, 429.3374$ ); (+)HRESIMS $m / z 453.3333\left[\mathrm{M}+\mathrm{Na}^{+}\right.$(calcd for $\mathrm{C}_{28} \mathrm{H}_{46} \mathrm{NaO}_{3}$, 453.3339); ${ }^{1} \mathrm{H}$ - and ${ }^{13} \mathrm{C}-\mathrm{NMR}$ data (see Table 3 ).

\subsection{Bioactivity Assay}

\subsubsection{Cell Lines}

American Type Culture Collection (Manassas, VA, USA) provided human epithelial kidney cells HEK293 (ATCC ${ }^{\circledR}$ no. CRL-1573 ${ }^{\mathrm{TM}}$ ) and melanoma cells SK-MEL-28 (ATCC ${ }^{\circledR}$ no. HTB-72 ${ }^{\mathrm{TM}}$ ). Human small intestine carcinoma cells HuTu80 and breast carcinoma cells ZR-75-1 were obtained from the Shared Research Facility's Vertebrate cell culture collection (Saint-Petersburg, Russia).

\subsubsection{Cell Culture Conditions}

HEK293 and SK-MEL-28 cells were cultured in Dulbecco's Modified Eagle Medium (DMEM), HuTu80 cells were maintained in Minimum Essential Medium (MEM), and ZR-75-1 cells were cultured in Roswell Park Memorial Institute Medium (RPMI-1640) in a humidified $5 \% \mathrm{CO}_{2}$ incubator. The culture medium was supplemented with $10 \%$ of fetal bovine albumin (FBS), $100 \mathrm{mg} / \mathrm{mL}$ streptomycin, and $100 \mathrm{U} / \mathrm{mL}$ penicillin. At $90 \%$ confluence, cells were rinsed with PBS, detached from the tissue culture flask by $0.25 \%$ trypsin $/ 0.5 \mathrm{mM}$ EDTA, and $10-20 \%$ of the harvested cells were transferred to a new flask containing fresh complete appropriate medium. The passage number was carefully controlled and the mycoplasma contamination was monitored on a regular basis.

\subsubsection{Preparation of Compounds for the Determination of Cytotoxic Activity}

Compounds 1, 4, and 5 and the mixture of 2 and 3 were dissolved in sterile dimethyl sulfoxide (DMSO) to prepare stock concentrations of $20 \mathrm{mM}$. Cells were treated with serially diluted 1-5 (10,50,100 $\mu \mathrm{M})$ (culture medium used as diluent) (final concentration of DMSO was less than $0.5 \%)$.

Doxorubicin (Doxo) (Teva Pharmaceutical Industries, Ltd., Petah Tikva, Israel) was dissolved in sterile PBS to prepare stock concentrations of $10 \mathrm{mM}$. Cells were treated with serially diluted Doxo $(5,25,50,100 \mu \mathrm{M})$ (culture medium used as diluent). 
The vehicle control is the cells treated with the equivalent volume of DMSO (final concentration was less than $0.5 \%$ ) for all of the presented experiments.

\subsubsection{Formation of 3D Spheroids by Liquid Overlay Technique (LOT)}

SK-ME-28, HuTu80, and ZR-75-1 spheroids were formed by the liquid overlay technique (LOT) method with slight modifications. Briefly, to create non-adherent surfaces for the efficient spheroids' formation, $50 \mu \mathrm{L}$ of preheated $\left(60^{\circ} \mathrm{C}\right)$ agarose $(1.5 \%)$ was overlaid the bottom of 96-well plates and left to solidify for $1 \mathrm{~h}$ at room temperature under sterile conditions.

SK-MEL-28 cells $\left(5.0 \times 10^{3}\right)$, HuTu80 $\left(3.0 \times 10^{3}\right)$, and ZR-75-1 $\left(3.0 \times 10^{3}\right)$ were inoculated in an agarose layer and cultured in $200 \mu \mathrm{L}$ of a complete appropriate culture medium for $96 \mathrm{~h}$ at $37^{\circ} \mathrm{C}$ in a $5 \% \mathrm{CO}_{2}$ incubator. An image of each spheroid was made with a ZOE $^{\mathrm{TM}}$ Fluorescent Cell Imager (Bio Rad, Hercules, CA, USA). ImageJ software bundled with 64-bit Java 1.8.0_112 (NIH, Bethesda, MD, USA) was used to measure the spheroid integrity, diameter, and volume.

\subsubsection{Cytotoxic Activity Assay (MTS)}

2D Cell Culture (Monolayer)

HEK293 $\left(0.8 \times 10^{3} / 200 \mu \mathrm{L}\right)$, SK-MEL-28 $\left(0.8 \times 10^{3} / 200 \mu \mathrm{L}\right)$, HuTu80 $\left(1.0 \times 10^{3} / 200 \mu \mathrm{L}\right)$, and ZR-75-1 $\left(1.2 \times 10^{3} / 200 \mu \mathrm{L}\right)$ cells were seeded into 96-well plates (Jet Biofil, Guangzhou, China) for $24 \mathrm{~h}$ at $37{ }^{\circ} \mathrm{C}$ in a $5 \% \mathrm{CO}_{2}$ incubator. Then cell monolayer was treated either with DMSO (control), Doxo (positive control) $(5,25,50,100 \mu \mathrm{M})$ or various concentrations of compounds $\mathbf{1}, \mathbf{4}$, and 5 and the mixture of 2 and $\mathbf{3}(10,50,100 \mu \mathrm{M})$ in fresh appropriate culture medium for $24 \mathrm{~h}$. Subsequently, the cells were incubated with $15 \mu \mathrm{L}$ of 3-(4,5-dimethylthiazol-2-yl)-5-(3-carboxymethoxyphenyl)-2-(4-sulfophenyl)-2Htetrazolium (MTS reagent) (Promega, Madison, WI, USA) for $3 \mathrm{~h}$, and the absorbance of each well was measured at 490/630 nm using Power Wave XS microplate reader (BioTek, Wynusky, VT, USA). The concentration at which the compounds exert half of its maximal inhibitory effect on cell viability $\left(\mathrm{IC}_{50}\right)$ was calculated by the AAT-Bioquest ${ }^{\circledR}$ online calculator [31].

\section{D Cell Culture (Spheroids)}

The spheroids were treated by replacing $100 \mu \mathrm{L}$ of supernatant with a complete medium containing DMSO (control), Doxo (positive control) at 5, 25, 50, $100 \mu \mathrm{M}$ or compounds 1, 4, and 5 and the mixture of 2 and 3 at 10, 50, $100 \mu \mathrm{M}$ for $24 \mathrm{~h}$. Then, $15 \mu \mathrm{L}$ of 3-(4,5-dimethylthiazol-2-yl)-5-(3-carboxymethoxyphenyl)-2-(4-sulfophenyl)-2Htetrazolium (MTS) reagent (Promega, Madison, WI, USA) was added to each well with spheroids and incubated for $3 \mathrm{~h}$ at $37^{\circ} \mathrm{C}$ in a $5 \% \mathrm{CO}_{2}$ incubator. The absorbance of each well was measured at $490 / 630 \mathrm{~nm}$ using Power Wave XS microplate reader. A photo of the 3D spheroids ( $40 \times 200 \mu \mathrm{m}$ scale) was made with the aid of a microscope Motic AE 20 (XiangAn, Xiamen 361101, China) and the ImageJ software.

\subsubsection{Statistical Analysis}

All of the assays were performed in at least three independent experiments. Results are expressed as the mean \pm standard deviation (SD). The Student's $t$-test was used to evaluate the data with the following significance levels: ${ }^{*} p<0.05,{ }^{* *} p<0.01,{ }^{* * *} p<0.001$.

\section{Conclusions}

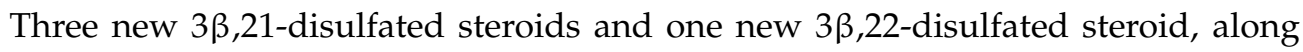
with a previously known related compound, were isolated from the Far Eastern starfish P. marsippus, and their chemical structures were established. Two steroids have an oxogroup at position C-7 in steroid nucleus; moreover, one of them additionally includes the conjugated 5,6-double bond. The $\Delta^{24}$-22-sulfoxycholestane side chain, indicated in another new steroid, has not been earlier found in starfish and ophiuroid steroidal compounds. 
Thus, in one more species of starfish, P. marsippus, belonging to the Pterasteridae family, like the previously studied six species of starfish of the same family, disulfated steroids of «the ophiuroid type» were found. It should be noted that the polyhydroxylated compounds and asterosaponins common in starfish were absent in the P. marsippus as well as in the previously studied species of this family. This fact once again confirms the assumption about a closer phylogenetic relationship between Asteroidea and Ophiuroidea classes compared to other classes of Echinodermata. The mixture of two steroids, having an oxogroup at position C-7 in steroid nucleus, was found to possess the highest cytotoxic activity against 2D and 3D human breast carcinoma cells ZR-75-1 among other investigated by us compounds and can be a candidate for further examination of the molecular mechanism of its anticancer action.

Supplementary Materials: The following are available online at https:/ /www.mdpi.com/article/10 $.3390 / \mathrm{md} 20030164$ /s1, Copies HRESIMS (Figures S1, S14-S18, S31 and S38), 1H-NMR (Figures S2, S8, S19, S25, S32, and S39), 13C-NMR (Figures S3, S9, S20, S26, S33, and S40), COSY (Figures S4, S10, S21, S27, S34, and S41), HSQC (Figures S5, S11, S22, S28, S20, S35, and S42), HMBC (Figures S6, S12, S23, S29, S36, and S43), and ROESY (Figures S7, S13, S24, S30, S37, and S44) spectra of compounds 1 , the mixture of 2 and 3, 2a, 3a, 4, and 5, respectively. COSY, key HMBC, and key ROESY correlations of compounds 2a and 3a (Figure S18).

Author Contributions: Conceptualization, A.A.K. and O.S.M.; data curation, A.I.K. and R.S.P.; funding acquisition, V.A.S.; investigation, A.A.K., A.I.K., O.S.M. and R.S.P.; methodology, A.A.K., A.I.K., T.V.M., O.S.M., R.S.P. and N.V.I.; writing-original draft, A.A.K. and O.S.M.; writing-review and editing, T.V.M., S.P.E., V.A.S. and N.V.I. All authors have read and agreed to the published version of the manuscript.

Funding: This research was funded by RFBR (Russian Foundation for Basic Research), grant number 20-03-00014.

Institutional Review Board Statement: Not applicable.

Informed Consent Statement: Not applicable.

Data Availability Statement: Not applicable.

Acknowledgments: The study was carried out on the equipment of the Collective Facilities Center - The Far Eastern Center for Structural Molecular Research (NMR/MS) of PIBOC FEB RAS. We are grateful to B.B. Grebnev (G.B. Elyakov Pacific Institute of Bioorganic Chemistry FEB RAS, Vladivostok, Russia) for species identification of the starfish.

Conflicts of Interest: The authors declare no conflict of interest.

\section{References}

1. Kornprobst, J.M.; Sallenave, C.; Barnathan, G. Sulfated compounds from marine organisms. Comp. Biochem. Physiol. 1998, 119B, 1-51. [CrossRef]

2. Stonik, V.A. Marine polar steroids. Russ. Chem. Rev. 2001, 70, 673-715. [CrossRef]

3. Carvalhal, F.; Correia-da-Silva, M.; Sousa, E.; Pinto, M.; Kijjoa, A. SULFATION PATHWAYS: Sources and biological activities of marine sulfated steroids. J. Mol. Endocrinol. 2018, 61, T211-T231. [CrossRef] [PubMed]

4. Minale, L.; Riccio, R.; Zollo, F. Steroidal oligoglycosides and polyhydroxysteroids from Echinoderms. Fortschr. Chem. Org. Naturst. 1993, 62, 75-308. [CrossRef]

5. Stonik, V.A.; Ivanchina, N.V.; Kicha, A.A. New polar steroids from starfish. Nat. Prod. Commun. 2008, 3, 1587-1610. [CrossRef]

6. Ivanchina, N.V.; Kicha, A.A.; Stonik, V.A. Steroid glycosides from marine organisms. Steroids 2011, 76, 425-454. [CrossRef] [PubMed]

7. Dong, G.; Xu, T.H.; Yang, B.; Lin, X.P.; Zhou, X.F.; Yang, X.W.; Liu, Y.H. Chemical constituents and bioactivities of starfish. Chem. Biodivers. 2011, 8, 740-791. [CrossRef]

8. Ivanchina, N.V.; Kicha, A.A.; Malyarenko, T.V.; Stonik, V.A. Advances in Natural Products Discovery; Gomes, A.R., Rocha-Santos, T., Duarte, A., Eds.; Nova Science Publishers: Hauppauge, NY, USA, 2017; Volume 6, pp. 191-224.

9. Xia, J.M.; Miao, Z.; Xie, C.L.; Zhang, J.W.; Yang, X.W. Chemical constituents and bioactivities of starfishes: An update. Chem. Biodivers. 2020, 17, e1900638. [CrossRef]

10. Stonik, V.A.; Kicha, A.A.; Malyarenko, T.V.; Ivanchina, N.V. Asterosaponins: Structures, taxonomic distribution, biogenesis and biological activities. Mar. Drugs 2020, 18, 584. [CrossRef] 
11. D'Auria, M.V.; Finamore, E.; Minale, L.; Pizza, C.; Riccio, R.; Zollo, F.; Pusset, M.; Tirard, P. Steroids from the starfish Euretaster insignis: A novel group of sulphated 3ß,21-dihydroxysteroids. J. Chem. Soc. Perkin Trans. 1984, 1, 2277-2282. [CrossRef]

12. Levina, E.V.; Andriyaschenko, P.V.; Stonik, V.A.; Kalinovsky, A.I. Ophiuroid-type steroids in starfish of the genus Pteraster. Comp. Biochem. Physiol. B Biochem. Mol. Biol. 1996, 114B, 49-52. [CrossRef]

13. Levina, E.V.; Andriyaschenko, P.V.; Kalinovsky, A.I.; Stonik, V.A. New ophiuroid-type steroids from the starfish Pteraster tesselatus. J. Nat. Prod. 1998, 61, 1423-1426. [CrossRef] [PubMed]

14. Levina, E.V.; Andriyashchenko, P.V.; Kalinovsky, A.I.; Dmitrenok, P.S.; Stonik, V.A. Steroid compounds from the Far Eastern starfish Diplopteraster multipes. Russ. J. Bioorgan. Chem. 2002, 28, 189-193. [CrossRef] [PubMed]

15. Ivanchina, N.V.; Kicha, A.A.; Kalinovsky, A.I.; Dmitrenok, P.S.; Stonik, V.A. Hemolytic steroid disulfates from the Far Eastern starfish Pteraster pulvillus. J. Nat. Prod. 2003, 66, 298-301. [CrossRef] [PubMed]

16. Levina, E.V.; Kalinovsky, A.I.; Dmitrenok, P.S. Steroid compounds from the Far East starfish Pteraster obscurus and the ophiura Asteronyx loveni. Russ. J. Bioorg. Chem. 2007, 33, 341-346. [CrossRef]

17. Fu, X.; Schmitz, F.J.; Lee, R.H.; Papkoff, J.S.; Slate, D.L. Inhibitors of protein tyrosine kinase pp60 ${ }^{\mathrm{v}-\mathrm{src}}$ : Sterol sulfates from the brittle star Ophiarachna incrassata. J. Nat. Prod. 1994, 57, 1591-1594. [CrossRef]

18. McKee, T.C.; Cardellina, J.H.; Riccio, R.; D'Auria, M.V.; Iorizzi, M.; Minale, L.; Moran, R.A.; Gulakowski, R.J.; McMahon, J.B.; Buckheit, R.W.; et al. HIV-inhibitory natural products. 11. Comparative studies of sulfated sterols from marine invertebrate. J. Med. Chem. 1994, 37, 793-797. [CrossRef]

19. Sepe, V.; Bifulco, G.; Renga, B.; D'Amore, C.; Fiorucci, S.; Zampella, A. Discovery of sulfated sterols from marine invertebrates as a new class of marine natural antagonists of farnesoid-X-receptor. J. Med. Chem. 2011, 54, 1314-1320. [CrossRef]

20. Gazha, A.K.; Ivanushko, L.A.; Levina, E.V.; Fedorov, S.N.; Zaporozets, T.S.; Stonik, V.A.; Besednova, N.N. Steroid sulfates from ophiuroids (brittle stars): Action on some factors of innate and adaptive immunity. Nat. Prod. Commun. 2016, 11, 749-752. [CrossRef]

21. Kicha, A.A.; Kalinovsky, A.I.; Antonov, A.S.; Radchenko, O.S.; Ivanchina, N.V.; Malyarenko, T.V.; Savchenko, A.M.; Stonik, V.A. Determination of C-23 configuration in (20R)-23-hydroxycholestane side chain of steroid compounds by ${ }^{1} \mathrm{H}$ and ${ }^{13} \mathrm{C}$ NMR spectroscopy. Nat. Prod. Commun. 2013, 8, 1219-1222. [CrossRef]

22. D'Auria, M.V.; Riccio, R.; Minale, L.; La Barre, S.; Pusset, J. Novel marine steroid sulfates from Pacific ophiuroids. J. Org. Chem. 1987, 52, 3947-3952. [CrossRef]

23. Hamdy, A.-H.A.; Aboutabl, E.A.; Sameer, S.; Hussein, A.A.; Díaz-Marrero, A.R.; Darias, J.; Cueto, M. 3-Keto-22-epi-28-norcathasterone, a brassinosteroid-related metabolite from Cystoseira myrica. Steroids 2009, 74, 927-930. [CrossRef] [PubMed]

24. Nes, W.R.; Varkey, T.E.; Krevitz, K. The stereochemistry of sterols at C-20 and its biosynthetic implications. J. Am. Chem. Soc. 1977, 99, 260-262. [CrossRef] [PubMed]

25. Vanderach, D.J.; Djerassi, C. Marine natural products. Synthesis of four naturally occurring 20.beta.-H cholanic acid derivatives. J. Org. Chem. 1978, 43, 1442-1448. [CrossRef]

26. Amann, A.; Ourisson, G.; Luu, B. A novel stereospecific synthesis of 22-hydroxylated triterpenes and steroids: Syntheses of 22R-hydroxylanosterol and 22R-hydroxydesmosterol. Synthesis 1987, 1987, 696-700. [CrossRef]

27. Hietter, H.; Trifilieff, E.; Richert, L.; Beck, J.-P.; Luu, B.; Ourisson, G. Antagonistic action of cholesterol towards the toxicity of hydroxysterols on cultured hepatoma cells. Biochem. Biophys. Res. Commun. 1984, 120, 657-664. [CrossRef]

28. Ivanchina, N.V.; Kicha, A.A.; Malyarenko, T.V.; Kalinovsky, A.I.; Dmitrenok, P.S.; Stonik, V.A. Biosynthesis of polar steroids from the Far Eastern starfish Patiria (=Asterina) pectinifera. Cholesterol and cholesterol sulfate are converted into polyhydroxylated sterols and monoglycoside asterosaponin $\mathrm{P}_{1}$ in feeding experiments. Steroids 2013, 78, 1183-1191. [CrossRef]

29. Amelian, A.; Wasilewska, K.; Megias, D.; Winnicka, K. Application of standard cell cultures and 3D in vitro tissue models as an effective tool in drug design and development. Pharmacol. Rep. 2017, 69, 861-870. [CrossRef]

30. Edmondson, R.; Broglie, J.J.; Adcock, A.F.; Yang, L. Three-dimensional cell culture systems and their applications in drug discovery and cell-based biosensors. Assay Drug Dev. Technol. 2014, 12, 207-218. [CrossRef]

31. AAT Bioquest. Available online: https:/ / www.aatbio.com/tools/ic50-calculator (accessed on 10 November 2020). 